\title{
Sustainable agriculture in the semi-arid tropics through biological nitrogen fixation in grain legumes
}

S.P. Wani, O.P. Rupela and K.K. Lee

International Crops Research Institute for the Semi-Arid Tropics (ICRISAT), Patancheru 502 324, Andhra

Pradesh, India

Key words: inoculation, legumes, nonnodulation, rhizobia, residual effects, symbiotic $\mathrm{N}_{2}$ fixation

\section{Table of contents}

Abstract

Introduction

Contribution of BNF to $\mathrm{N}$ balance

Beneficial effects of legumes

Nitrogen effect

Non- $\mathrm{N}$ rotational effects

Ways to improve BNF in the SAT

Host-related aspects

Host-variability for nodulation and nitrogen fixation

Breeding for increased BNF and nitrate tolerance

Management practices

Nitrogen

Intercropping

Tillage

Land form

Deep sowing

Other nutrients

Insects

Use of inoculants

Need for inoculation

Competitive and effective strains

Factors affecting performance of inoculant strains

Yield responses to inoculation.

Conclusion and future areas of research

Acknowledgements

References 


\begin{abstract}
Sustainable agriculture relies greatly on renewable resources like biologically fixed nitrogen. Biological nitrogen fixation plays an important role in maintaining soil fertility. However, as BNF is dependent upon physical, environmental, nutritional and biological factors, mere inclusion of any $\mathrm{N}_{2}$-fixing plant system does not guarantee increased contributions to the soil $\mathrm{N}$ pool. In the SAT where plant stover is also removed to feed animals, most legumes might be expected to deplete soil $\mathrm{N}$. Yet beneficial legume effects in terms of increased yields in succeeding cereal crops have been reported. Such benefits are partly due to $\mathrm{N}$ contribution from legumes through $\mathrm{BNF}$ and soil $\mathrm{N}$ saving effect. In addition, other non- $\mathrm{N}$ rotational benefits, for example, improved nutrient availability, improved soil structure, reduced pests and diseases, hormonal effects are also responsible. In this paper we have reviewed the research on the contribution of grain legumes in cropping systems and the factors affecting BNF. Based on the information available, we have suggested ways for exploiting BNF for developing sustainable agriculture in the semi-arid tropics (SAT). A holistic approach involving host-plant, bacteria, environment and proper management practices including need based inoculation for enhancing BNF in the cropping systems in the SAT is suggested.
\end{abstract}

\section{Introduction}

Sustainable agriculture involves the successful management of agriculture resources to satisfy changing human needs while maintaining or enhancing the environment quality and conserving natural resources (TAC, CGIAR, 1988). Sustainable agriculture relies greatly on renewable resources and on-farm nitrogen contributions are achieved largely through biological nitrogen fixation (BNF). Biological nitrogen fixation helps in maintaining and/or improving soil fertility by using $\mathrm{N}_{2}$ which is in abundance in the atmosphere. Above every hectare of land at sea level, there is 78,000 tones of inert nitrogen gas $\left(\mathrm{N}_{2}\right)$. Intensive agricultural systems are characteristically expanded nutrient cycles involving the export of crops from a farm and require continued import of nutrients to the farm.

Nitrogen is the most limiting nutrient for increasing crop productivity. Input efficiency of $\mathrm{N}$ fertilizer is low (Prasad et al., 1990) and in turn, contributes substantially to environmental pollution. The continued and unabated use of $\mathrm{N}$ fertilizers would further deplete stocks of nonrenewable fossil fuels used in fertilizer production.

Annually, BNF is estimated to be around 175 million tones $N$ of which close to $79 \%$ is accounted for by terrestrial fixation (Fig. 1). This illustrates the importance of BNF in the context of the global $N$ cycle. The $\mathrm{BNF}$ offers an economically attractive and ecologically sound means of reducing external $N$ inputs and improving the quality and quantity of internal resources. In this paper we deal with the BNF systems involving upland grain legume crops grown in the semi-arid tropics (SAT). The SAT are the areas located in the seasonally dry tropical climates, spread over four continents.
The mean annual temperature in the SAT is $>18^{\circ} \mathrm{C}$; rainfall exceeds potential evapotranspiration for only 2 to 4.5 months in the dry SAT and for 4.5 to 7 month $/$ in the wet/dry SAT (Troll, 1965).

\section{Contribution of BNF to $\mathrm{N}$ balance}

Accurate estimation of the amount of $\mathrm{N}_{2}$ fixed by different crops in a particular agro-ecosystem is a prerequisite for assessing and improving the contribution of $\mathrm{BNF}$ to a given cropping system. However, as nitrogen fixation is dependent upon physical, environmental, nutritional and biological factors (Chalk, 1991; Nambiar et al., 1988; Peoples and Crasswell, 1992) it can not be assumed that any $\mathrm{N}_{2}$-fixing system will automatically contribute to the $\mathrm{N}$ cycle. In general while estimating BNF, plant roots and fallen leaf material are not taken into account which results in underestima-

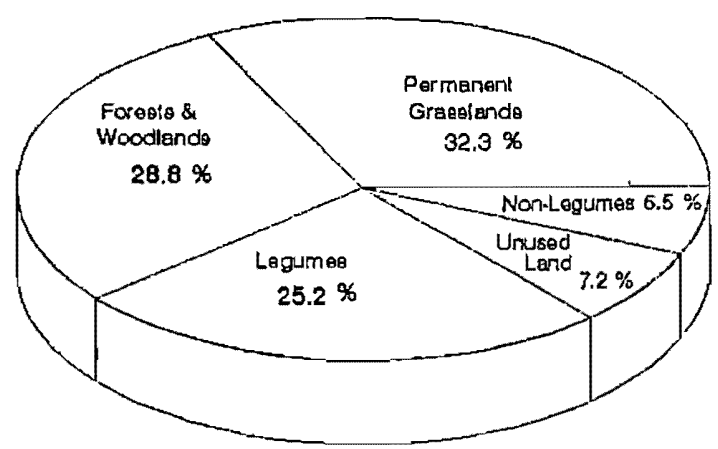

Fig. 1. Distribution of 139 million tonnes of $\mathrm{N}_{2}$ estimated to be biologically fixed in various terrestrial systems. Source: Bums and Hardy (1975). 
Table 1. Examples of estimates of nitrogen fixed by some legumes

\begin{tabular}{ll}
\hline Crop & Nitrogen fixed $\left(\mathrm{kg}^{\text {ha }}{ }^{-1}\right)$ \\
\hline Alfalfa & $100-300$ \\
Black gram & $119-140$ \\
Clover & $100-150$ \\
Chickpea & $23-97$ \\
Cluster bean & $37-196$ \\
Common bean & $3-57$ \\
Cuwpea & $9-125$ \\
Groundnut & $27-206$ \\
Lentil & $35-100$ \\
Greengram & $50-66$ \\
Pigeonpea & $4-200$ \\
Rice bean & $32-97$ \\
Soybean & $49-450$ \\
Peas & 46 \\
Fenugreek & 44 \\
\hline
\end{tabular}

Sturrees: Derived from Wani and Lee (1992) and Pecples and Crasswell (1992).

tion of the quantity of $\mathrm{N}_{2}$ fixed. It is essential that BNF in roots and fallen plant material $\mathrm{e}, \mathrm{g}$. leaves should be considered when estimating the amount of $\mathrm{N}_{2}$ fixed by legumes.

Legumes have been an important component of agriculture since ancient times. It is widely believed that legurnes improve soil fertility because of their $\mathrm{N}_{2}$ fixing ability. In support of this argument, the reported amounts of $\mathrm{N}_{2}$ fixed by legumes are cited (Table 1). However, in order to assess the role of BNF in the sustainability of different SAT cropping systems not only the amount of nitrogen fixed by the legume component crop in the system is important, but the overall nitrogen balance of the system needs to be considered. The SAT is characterized by a harsh environment with erratic seasonal rainfall and dense human and animal population and it has unique problems in agriculture also. Due to heavy pressure on land for production to feed a large human and animal population, it is a common practice that along with legume grains, plant material is also often taken away from the field for feeding the animals. In such a case only nodulated roots and fallen leaves go back to the soil.

Net nitrogen balances calculated for different cultivars of pigeonpea grown at Patancheru, India (Kumar Rao and Dart, 1987) and chickpea grown at Gwalior, India (Rupela et al., pers. commun.) indicated that all
Table z. Net nitrogen balance for pigeonpea and chickpes cultivars grown at Patancheru and Gwalior (India) respectively

\begin{tabular}{|c|c|c|c|c|}
\hline \multirow[b]{2}{*}{ Plgeonpeat } & \multirow[t]{2}{*}{$\begin{array}{l}\text { Total plant } \\
\text { N uptake } \\
\left(\mathrm{kg} \mathrm{ha}^{-1}\right)\end{array}$} & \multicolumn{2}{|c|}{$\begin{array}{l}\text { Plant } \mathrm{N} \text { derived frem } \\
\text { fixation ( } \mathrm{kg} \mathrm{ha}^{-1} \text { ) }\end{array}$} & \multirow[t]{2}{*}{$\begin{array}{l}\text { Net } \\
\text { balance } \\
(\mathrm{kg} \mathrm{ha}-1)^{-1}\end{array}$} \\
\hline & & & & \\
\hline Prabhat & 69 & 4 & & -49 \\
\hline UPAS 120 & 92 & 27 & & -39 \\
\hline T 2I & 108 & 43 & & -39 \\
\hline BDN 1 & 118 & 53 & & -32 \\
\hline Bhedlaghat & 101 & 36 & & -20 \\
\hline JA. 275 & 78 & 13 & & -33 \\
\hline Bhandara & 108 & 43 & " & -22 \\
\hline NP (WR) 15 & 114 & 50 & & -27 \\
\hline Chickpea & & & * & \\
\hline Annigeri & 110 & 31 & & -77 \\
\hline 0130 & 104 & 26 & & -75 \\
\hline $\operatorname{ICC} 435$ & 102 & 29 & : & -72 \\
\hline $1 \mathrm{CCC} 42$ & 88 & 23 & & -64 \\
\hline ICCV 6 & 107 & 30 & & -76 \\
\hline K 850 & 104 & 40 & & -63 \\
\hline
\end{tabular}

Source: Derived from Kumar Rao and Dart (1987) and Rupela et al. (pers. commun.. $)_{x}$

a $N$ et $N$ balance calculated as total plant $N$ uptake - ( $N$ derived from $\mathrm{BNF}+\mathrm{N}$ derived form fertilizer $+\mathrm{N}$ added to the sol through plant roots and fallen plant parts).

${ }^{b}$ BNF was estimated by $N$ difference method. $N$ derived from fixation calculated for roots also.

${ }^{6} \mathrm{BNF}$ was estimated by ${ }^{13} \mathrm{~N}$ based A-value method. $\mathrm{N}$ derived from fixation calculated for above ground plant parts only.

studied varieties depleted soil nitrogen (Table 2). In all these cases above ground plant materials were removed from the field. In the case of pigeonpea for computing nitrogen fixation, $\mathrm{N}$ in plant roots and fallen plant parts also was accounted for. Different maturity groups of pigeonpea cultivars fixed $4-53 \mathrm{~kg} \cdot \mathrm{N}$ ha ${ }^{-1}$ season $^{-1}$ while depleting $20-49 \mathrm{~kg} \mathrm{~N}^{-1}$ from the soil. In the case of chickpea, different cultivars fixed 23-40 $\mathrm{kg} \mathrm{N} \mathrm{ha}^{-1}$ season $^{-1}$ and removed $63-77 \mathrm{~kg} \mathrm{~N} \mathrm{ha}^{-1}$ season ${ }^{-1}$ from the soil (Table 2). Groundnut fixed 190 $\mathrm{kg} \mathrm{N}^{-1}$ season $^{-1}$ when pod yields were around 3.5 $t_{\text {ha }}-1$ at Patancheru (Nambiar et al., 1986), however, groundnut relied for its $20-40 \%\left(47-127 \mathrm{~kg} \mathrm{~N} \mathrm{ha}^{-1}\right.$ season $^{-1}$ ) of the $\mathrm{N}$ requirement on soil or from fertilizer (Giller et al., 1987), obviously resulting in a negative $\mathrm{N}$ balance. Positive net $\mathrm{N}$ balances of up to $136 \mathrm{~kg} \mathrm{ha}^{-1}$ for several legume crops following seed harvest have been shown by Peoples and Craswell (1992). However, 
Table 3. Nitrogen balance sheet* for different cropping systems for Alfisol, Parancheru, India

\begin{tabular}{|c|c|c|c|c|c|c|c|c|}
\hline \multirow{2}{*}{\multicolumn{2}{|c|}{$\begin{array}{l}\text { Cropping system } \\
\text { by year }\end{array}$}} & \multicolumn{4}{|c|}{ Import $\left(\mathrm{kg} \mathrm{h}^{-1}\right)=(\mathrm{A})$} & \multicolumn{2}{|c|}{ Export $\left(\mathrm{kg} \mathrm{ha}^{-1}\right)^{\circ}(\mathrm{B})$} & \multirow{3}{*}{ Balanice $(\mathrm{kg} \mathrm{ha}-1)(A)-(B)$} \\
\hline & & \multicolumn{2}{|c|}{ Fertilizer } & \multicolumn{2}{|c|}{$\begin{array}{l}\text { Leguminous }{ }^{d} \\
\mathrm{~N}_{2} \text {-fixation }\end{array}$} & \multicolumn{2}{|l|}{ Harvest" } & \\
\hline 1991 & 1992 & 1991 & 1992 & 1991 & 1992 & 1991 & $1992^{f}$ & \\
\hline$\$ / P$ & $c$ & 60 & 60 & $0 \div 80$ & 0 & $88 \div 68$ & 66 & -22 \\
\hline$c$ & $\mathrm{~S} / \mathrm{P}$ & 60 & 60 & 0 & $0 \div 46$ & 64 & $93+46$ & -37 \\
\hline $\mathrm{G} / \mathrm{P}$ & $c$ & 18 & 60 & $90+50$ & 0 & $108+56$ & 72 & -18 \\
\hline C & $\mathrm{G} / \mathrm{P}$ & 60 & 18 & 0 & $102 \div 82$ & 65 & $141+75$ & -19 \\
\hline$P$ & $\mathrm{C}$ & 18 & 60 & 121 & 0 & 115 & 66 & +18 \\
\hline
\end{tabular}

${ }^{a} \mathrm{~N}$ balance calculated based on main import and export sources of $\mathrm{N}$.

${ }^{b} \mathrm{~S} / \mathrm{P}=$ Sorghum intercropped with pigeonpea, $\mathrm{C}=\mathrm{castor}_{*} \mathrm{G} / \mathrm{P}=$ groundnut intercropped with pigeonpea, and $\mathrm{P}=$ sole pigeonpca.

Each value within a binomial corresponds to the crop in intercrop.

dincluding atmosphere-derived $N$ (fxed $N$ ) in legurminous roots.

"Assumed that groundnut roots were exported by harvest.

i $\mathrm{N}$ contents in mini-plot grown sorghum, pigeonpen, and ground nut were uscd to calculate total $\mathrm{N}$ in the harvest for 1992.

Source: Lee et al. (1993).

if crop residues were removed from the field then net $\mathrm{N}$ balances for groundnut are -27 to -95 , for soybean -28 to -104 , common bean -28 , greengram -24 to -65 and cowpea -25 to $-69 \mathrm{~kg} \mathrm{ha}^{-1}$. Similarly, for soybean grown with different starter $\mathrm{N}$ levels after rice which received different fertilization levels, the $\mathrm{N}$ balances with seed and stover removed ranged from -12 to $-35 \mathrm{~kg} \mathrm{ha}^{-1}$ in northern Thailand (Jefing et al., 1992). For different cropping systems where pigeonpea and groundnut are grown as intercrops, nitrogen balances were negative (Lee et al., 1993). In the case of sole pigeonpea grown in rotation with sole castor, a positive balance of $18 \mathrm{~kg} \mathrm{Nha}^{-1}$ during two years crop rotation was observed at Patancheru (Table 3). These results show that legumes also mine the soil $\mathrm{N}$ as cereals do. However, total plant $N$ yields from legumes are far higher than the cereal plant $N$ yields. We reach the conclusion that in general, grain legumes, where crop residues are removed, slow the decline of, rather than enhance, the $\mathrm{N}$ fertility of the soil in comparison with cereal systems.

\section{Beneficial effects of legumes}

Despite the negative $\mathrm{N}$ balances for grain legumes grown in rotation or as intercrops, reported benefits of legumes to succeeding non-legume crops have been observed consistently (Table 4). Improvement in cereal yield following monocropped legumes lie mainly in the 0.5 to $3 \mathrm{tha}^{-1}$ range, representing around 30 to $350 \%$ increase over yields in cereal-cereal cropping sequences (Peoples and Crasswell, 1992). In a longterm crop rotation experiment conducted since 1983 at ICRISAT Center, Patancheru, mean residual effects of legume-based crop rotations over the last ten years were observed on sorghum yield as compared to the yield of sorghum from sorghum + safflower $(S+F)-S+F$ plots (Fig. 2). Such increased cereal yields following legume crops were attributed to the $\mathrm{N}$ contribution from legumes in crop rotation (De et al., 1983; Kumar Rao et al., 1983; Nambiar, 1990). This opinion is not held by all (Cook, 1988; Danso and Pappastylianou, 1992; Fyson and Oaks, 1990; Russelle ot al. 1987; Wani et al., 1991a, 1994a).

\section{Nitrogen effect}

Terms like "N residual effect" (De et al., 1983) and "Fertilizer N replacement value" or N equivalent (Hesterman et al., 1987) are used to describe the role of legumes in crop rotations. They refer to the amount of inorganic $\mathrm{N}$ required following a non-legume crop to produce another non-legume crop with an equivalent yield to that obtained following a legume. This comparison provides a quantitative estimate of the amount of $\mathrm{N}$ that the legume supplies to the non-legume crop. This concept does not distinguish between BNF and the "N-conserving effect" which results from substitution by legumes of biologically fixed $\mathrm{N}$ for soil $\mathrm{N}$. Fertilizer $N$ replacement value (FRV) methodology has been widely used but it overestimates the $\mathrm{N}$ contribu- 
Table A. Residual effect of preceding legume on cereal yield in terms of fertillzer $N$ equivalents

\begin{tabular}{|c|c|c|}
\hline $\begin{array}{l}\text { Preceding } \\
\text { legume }\end{array}$ & $\begin{array}{l}\text { Following } \\
\text { cereal }\end{array}$ & $\begin{array}{c}\text { Fertilizer } \mathrm{N} \\
\text { equivalent }\left(\mathrm{kg} \mathrm{ha}^{-1}\right)\end{array}$ \\
\hline Berseem & Maize & 123 \\
\hline Swet clover & Matze & 83 \\
\hline Winged bean & Maize & 70 \\
\hline Blackgram & Sorghum & 68 \\
\hline Greengram & Sorghum & 68 \\
\hline Greengram (monocrop) & Wheat & 68 \\
\hline Chickpea & Maize & $60-70$ \\
\hline Cowpea & Maize & 60 \\
\hline Groundnut & Pearl millet & 60 \\
\hline Cowpea & Pearl miller & 50 \\
\hline Chickpea & Pearl millet & 40 \\
\hline Lentil & Pearl millet & 40 \\
\hline Peas & Peari millet & 40 \\
\hline Pigeonpea & Wheat & 40 \\
\hline Cowpea (monocrop) & Wheat & 38 \\
\hline Lathyrus & Maize & $36-48$ \\
\hline Lablab bean & Maize & 33 \\
\hline Pigeonpea & Pearl miller. & 30 \\
\hline Greengram & Pearl millet & $\cdot 30$ \\
\hline Groundnut (monocrop) & Wheat & 28 \\
\hline Pigeonpera & Maize & $20-67$ \\
\hline Peas & Maize & $20-32$ \\
\hline Lentil & Maize & $18-30$ \\
\hline Greengram (intercrop) & Wheat & 16 \\
\hline Cowpea (intecrop) & Wheat & 13 \\
\hline Groundnut (intercrop) & Wheat & 12 \\
\hline Groundnut & Maize & $9-60$ \\
\hline Soybean & Maize & 7 \\
\hline
\end{tabular}

Source: Derived from Ahlawat et al. (1981), Bendyopadhyay and De (1986), Chandra and Alt (1986), Dakora et al. (1987), De and Goutam (1987), Doughton and MacKenzie (1984), MacCol (1989), Nambiar et al. (1988), Roy Sharma and Singh (1969), and Weil and Samaranayake (1991).

1

tion of legumes in a crop rotation. The FRV methodology gives variable estimates depending on the test crop used. The $\mathrm{N}$ contribution from hairy vetch and big flower vetch was estimated to be 65 and $75 \mathrm{~kg}$ $\mathrm{N} \mathrm{ha}{ }^{-1}$ respectively with maize as test crop and 125 and $135 \mathrm{~kg} \mathrm{~N}^{-1}$ using grain sorghum (Blevins et al., 1990). Recently, ${ }^{15} \mathrm{~N}$ methodology has been used to measure the residual effects of legumes to circumvent problems with non-isotopic methods (Danso and Papastylianou, 1992; Senaratne and Hardarson, 1988; Wani et al., 1991a). Based on the estimates obtained

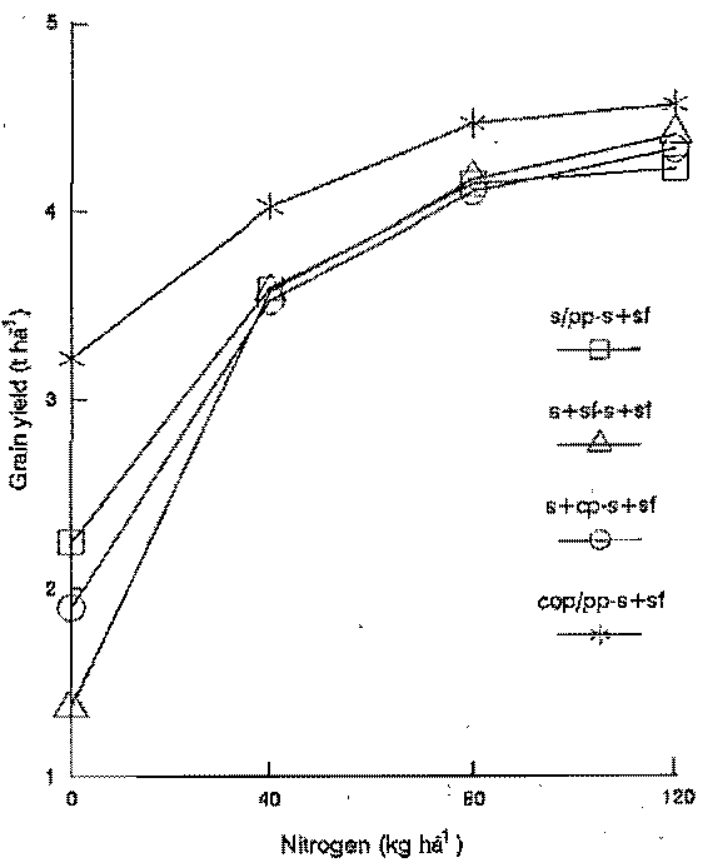

Fig. 2. Mear gain yield of sorghum grown in rainy sessons (1983-92) sucteding different cropping system in previous year, ICRISAT, Patanchent. (2 year crop rotation) S - sorghum, PF pigeonpea, SF - safflower, CP - chickpea, COP - cowpea, / - intercropped, + - sole crop grown during postrainy seagon. Source: Rego and Burford (1992).

via ${ }^{15} \mathrm{~N}$ methodology, Hesterman et al. (1987) argued that the amount of $N$ credited to legumes in a crop rotation in the north-central US may be inflated by as much as $123 \%$ due to the use of the FRV method. Based on ${ }^{15} \mathrm{~N}$ methodology it is reported that only 7.3 to $28 \%$ of the ${ }^{15} \mathrm{~N}$ in legume crops is taken up by following grain crop (Ladd et al., 1981, 1983; Vallis. 1983; Wani, unpubl. data). The overestimation is because the FRV method confounds the non-N rotation effect with the $\mathrm{N}$ contribution, and this method assumes that use efficiency of fertilizer and legume $\mathrm{N}$ is similar.

Growing legumes in rotation does improve mineral $N$ content in soil as compared with the cultivation of non-legume crops. At ICRISAT-Asia Center, Patancheru, India, a long-tern rotation experiment is being conducted on a Vertisol since 1983 using twoyear crop rotation treatinents. The surface soil $(0-20$ $\mathrm{cm}$ ) samples collected after harvest of 9 th season crop showed in general higher amounts of mineral $\mathrm{N}$ contents in the soil from the legume-based cropping system than the non-legume based cropping system (Wani et al., 1994a; Fig. 3). Inclusion of greengram in the crop- 


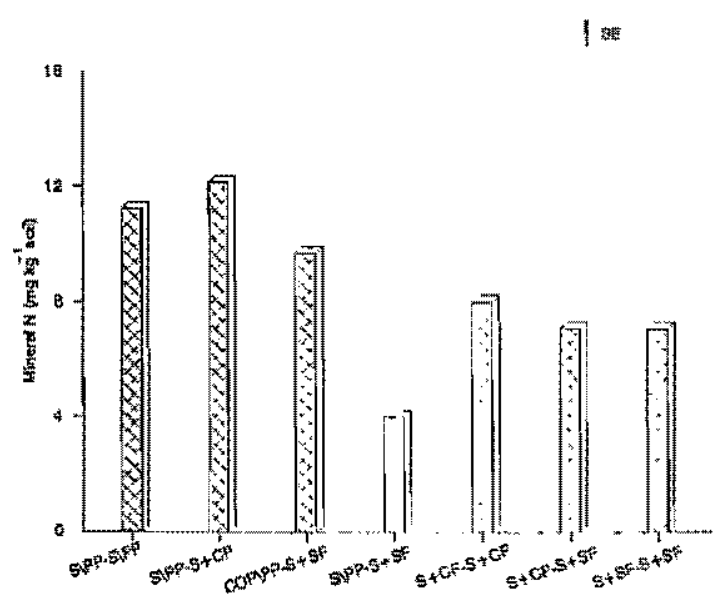

Fig. 3. Mineral $N$ content in surface soll samples $(0-20 \mathrm{~cm})$ from plots under different cropping systens since last nine years. S sorghum, PP - pigeonpea, SF - saftower, CP - chickpea, COPcowpea, $/$ - intercropped, + - sole crop grown during postrainy season.

ping sequence increased available nitrogen in the soil at haryest to the extent of $12.6 \%$ in the non-fertilized control plot (Rao and Singh, 1991). Similarly, a five times higher mineral $\mathrm{N}$ content in the soil under an eight year rotation using fababeans as green manure (agro-ecological rotation) was observed than from the soil under continuous barley treatment which was fertilized with $90 \mathrm{~kg} \mathrm{~N} \mathrm{ha}^{-1} \mathrm{y}^{-1}$ (Wani et al., 1991a).

In addition to mineral $\mathrm{N}$ content in the soil from the long-term rotation experiment, $\mathrm{N}$ mineralization potential $\left(\mathrm{N}_{0}\right)$ of the soils under pigeonpea based cropping system was almost two times higher as compared to the fallow-sorghum treatment (Table 5). The "active $\mathrm{N}$ fraction", the quotient of $\mathrm{N}_{0}$ and $\mathrm{N}_{\text {tosal }}$ and expressed as percentage, varied between 9-17\% with higher values reported for the soil under pigeonpeabased cropping systems (Wani et al, unpubl. data). Using $\mathrm{N}_{0}$ and $\mathrm{k}$ ( $\mathrm{N}$ mineralization rate constant) values the cropping systems were ranked based on the time required to mineralize $25 \mathrm{mg} \mathrm{N} \mathrm{kg}^{-1}$ soil. Time required to mineralize a fixed quantity of $N$ was less in the case of cropping systems which contained pigeonpea than the time required in the case of cropping systems which involved chickpea or no legume or which was left fallow for one season (Table 5). Such benefits in terms of increased "mineralizable $\mathrm{N}\left(\mathrm{N}_{\sigma}\right)$ " in the soil were observed even when all the above ground plant parts except fallen leaves were removed. Such increased $N_{0}$ values at Patancheru were not associated
Table 5. Nitrogen mineratization potential $\left(\mathrm{N}_{0}\right)$, active $\mathrm{N}$ fraction, and time (wk) required to mineralize $25 \mathrm{mg} \mathrm{N} \mathrm{kg}^{-1}$ soil for the soil samples under different cropping syztems

\begin{tabular}{|c|c|c|c|}
\hline Treatment $t^{a *}$ & $\begin{array}{l}\text { No } \\
\left(\mathrm{mg} \mathrm{kg} \mathrm{kg}^{-1} \text { soil }\right)\end{array}$ & $\begin{array}{l}\text { Active } N \\
\text { fraction( } 6)\end{array}$ & $\begin{array}{l}\text { Time (wk) to } \\
\text { mineralize } \\
25 \mathrm{mg} \mathrm{N} \mathrm{kg}^{-1} \text { soil }\end{array}$ \\
\hline SPP. SPP & $94.6 \pm 15.98$ & 13 & 10.3 \\
\hline$F+S-F+S$ & $40.5 \pm 8.06$ & 9 & 21.4 \\
\hline $\mathrm{COP} / \mathrm{PP}-\mathrm{S}+\mathrm{SF}$ & $86.1 \pm 19.90$ & 17 & 1.5 \\
\hline$S / P P-S+C P$ & $100 \pm 10.04$ & 16 & 13,8 \\
\hline $\mathrm{S} / \mathrm{PP}-\mathrm{S}+\mathrm{SF}$ & $67.3 \pm 13.46$ & & 10.1 \\
\hline $\mathrm{S}+\mathrm{SF}-\mathrm{S}+\mathrm{SF}$ & $3^{3}$ & $t^{6}$ & -6 \\
\hline $\mathrm{S}+\mathrm{CP}-\mathrm{S}+\mathrm{SF}$ & -4 & $-b$ & .6 \\
\hline$S+C P-S+C P$ & $56.1 \pm 20.98$ & & 19.6 \\
\hline
\end{tabular}

${ }^{a} \mathrm{~S}=$ sorghum, $\mathrm{PP}=$ pigeonpea, $\mathrm{F}=$ fallow during miny season, $\mathrm{COP}$ $=$ covpea, $\mathrm{SF}=$ saflower, $\mathrm{CP}=$ chickpea,$t=$ intercropped, + sole crop gtown during postrainy season.

Not estimated as exponential model was not superior over linea model.

Source: Wani et al. (unpubl. data).

with chickpea which is grown during the post rainy season on residual moisture. Mineralizable soil $\mathbf{N}\left(\mathbb{N}_{0}\right)$ following one cycle of an eight year rotation using fababeans as green manure was about double that fol lowing 60 years of a 5-year rotation involving forage and cereal crops but without returning the crop residues to the soil (Wani et al., 1994b).

The analysis of field soil samples collected prior to the start of the experiment in 1983 and later in 1993 showed that, in the case of Fallow+Sorghum $(\mathrm{F}+\mathrm{S})$ system, total soil $\mathrm{N}$ content was decreased by $72 \mu \mathrm{g} \mathrm{g}^{-1}$ soil after ten years. S+CP-S $\div$ SF and $S+S F-S \div S F$ plots also showed decreased total soil $\mathrm{N}$. The continuous greengram + sorghum maintained the soil $\mathrm{N}$ while a substantial increase in total $\mathrm{N}$ was observed in S/PP-S+SF and cowpeajpigeonpea sorghum+safflower (COP/PP $-\mathrm{S}+\mathrm{SF}$ ) systems. (Table 6: Wani et al., 1994a). These results demonstrated that pigeonpea-based cropping systems increased the total soil $\mathrm{N}$ substantially during ten years.

Sorghum was grown in the greenhouse using surface soil samples collected from the field plots which were under different cropping systems during the last 9 years. Sorghum grown in the soil from the COP/PP. S+SF plots yielded $63 \%$ higher as compared to the sorghum grown in the soil from the $\$+S F-S+S F$ plots. In other pigeonpea-based cropping systems, sorghum yielded $36-56 \%$ higher than that of sorghum yield from 
Table 6. Soil total N ( $\mu \mathrm{gg}^{-1}$ soil) in $0-15 \mathrm{~cm}$ and $15-30 \mathrm{~cm}$ layer under different cropping systems during 1983 and 1993

\begin{tabular}{|c|c|c|c|c|}
\hline \multirow[b]{3}{*}{ Cropping system } & \multicolumn{4}{|c|}{ Soll depth } \\
\hline & \multicolumn{2}{|c|}{$0-15 \mathrm{~cm}$} & \multicolumn{2}{|c|}{$15-20 \mathrm{~cm}$} \\
\hline & 1983 & 1993 & 1983 & 1993 \\
\hline $\mathrm{SPP}-\mathrm{S}+\mathrm{SF}$ & 559 & 629 & 437 & 480 \\
\hline $\mathrm{S}+\mathrm{CP}-\mathrm{S}+\mathrm{SF}$ & 540 & 517 & 407 & 443 \\
\hline $\mathrm{C} / \mathrm{PP}-\mathrm{S}+\mathrm{SF}$ & 543 & 645 & 419 & 501 \\
\hline $\mathrm{S}+\mathrm{SF}-\mathrm{S}+\mathrm{SF}$ & 537 & 530 & 397 & 438 \\
\hline $\mathrm{F}+\mathrm{S} \cdot \mathrm{F}+\mathrm{S}$ & 563 & 491 & 422 & 426 \\
\hline $\mathrm{F}+\mathrm{CP}-\mathrm{F}+\mathrm{S}$ & 567 & 507 & 399 & 446 \\
\hline \multirow[t]{3}{*}{$M+S-M+S$} & 558 & 559 & 422 & 461 \\
\hline & $N S$ & ** & NS & $* *$ \\
\hline & \pm 18.4 & \pm 132 & \pm 15.0 & 14.4 \\
\hline
\end{tabular}

3 - sorghum, PP - pigeonpea, SF \& saffiower, CP - chickpea, $C$ - cowpea, $F$ - fallow $M$ - mungbean, 1 - intercrop, + sequential crop, - - rotation, NS - Not significant. *** $p=0.01$. Source: Rego et al, (unpubl. data).

the $\mathrm{S}+\mathrm{SF}-\mathrm{S}+\mathrm{SF}$ treatment. In the case of chickpeabased cropping systems sorghum yields were lowered by $18-24.5 \%$ over the $\mathrm{S}+\mathrm{SF}-\mathrm{S}+\mathrm{SF}$ plot yields (Wani et al. unpubl. results). Using ${ }^{15} \mathrm{~N}$ methodology it was estimated that 8.4 to $20 \%$ of total sorghum plant $\mathrm{N}$ in the case of pigeonpea-based cropping systems was derived from the $\mathrm{N}$ that was either fixed previously and had accumulated, or the soil $\mathrm{N}$ that was made more available due to the presence of pigeonpea in the rotation. This was clear evidence of greater $\mathrm{N}$ availability in the case of pigeonpea-based cropping systems over the S+SF-S+SF system. These results were h conformity with the findings of increased $N_{0}$ potential of these soils reported in Table 5. The A values for the soil from pigeonpea-based cropping system plots were higher by 25.6 to $76.3 \mathrm{mg} \mathrm{pot}{ }^{-1}(4.5-13.3 \mathrm{~kg}$ $\mathrm{N} \mathrm{ha}^{-1}$ equivalent) than that of the S+SF-S+SF treatment. The fertilizer $N$ replacement values calculated for these treatments using soil from the $\mathrm{S}+\mathrm{SF}-\mathrm{S}+\mathrm{SF}$ treatment ranged from $65-161 \mathrm{mg} \mathrm{N}$ pot $^{-1}(24-28 \mathrm{~kg}$ $\mathrm{N} \mathrm{ha}^{-1}$ equivalent). All these results indicated that increased sorghum yields from the pigeonpeatbased cropping systems over the S+SF-S+SF system were partly due to the increased soil $\mathrm{N}$ availability and all the benefits can not be explained in terms of the $\mathrm{N}$ effects (Wani et al., unpubl. results).
In the agroecological eight year rotation (which included barley, fababean, barley, fababean, barley undersown to red clover and brome grass, forage, forage, forage) barley grown following fababeans (AER 1) yielded $105 \%$ higher than that of the barley grown after continuous barley (CG) for eight years with $90 \mathrm{~kg}$ $\mathrm{N} a^{-1} y^{-1}$. Using ${ }^{15} \mathrm{~N}$ methodology it was estimated that $48.5 \%$ (405 $\mathrm{mg} \mathrm{N}$ pot $^{-1}$ ) of total barley plant $\mathrm{N}$ in the case of the AER 1 treatment was derived from the $\mathrm{N}$ source that was not present in the soil from the $\mathrm{CG}$ treatment. The presence of legumes in the rotation gave an increased $N$ supplying capacity ( $A$ value) of the soils over those in the soil from the CG system (Wani et al., 1991a). These authors concluded that the soil $\mathrm{N}$ availability to plants contributed significantly to the higher soil fertility in the legume-based systems. However, increased $N$ availability contributed partly to the increased barley yields from legume-based rotations and other mechanisms than the $\mathrm{N}$ effect were also responsible for increased barley yields in these plots (Wani et al. 1991a). Similarly, non- $\mathrm{N}$ rotational benefits of the legumes towards yield of subsequent crop have been observed by many researchers (Cook, 1988; Danso and Papastylianou, 1992; Peoples and Craswell, 1992; Weil and Samaranayake, 199.1).

\section{Non- $N$ rotational effects}

If the benefits of crop legumes in rotations cannot be solely explained in terms of the residual fixed $\mathrm{N}$, then what are the sources of the benefits demonstrated in Table 4? Several factors can be involved, the relative importance of each dictated by site, season, and crop. sequences.

Crop rotations increased the availability of nutrients other than $\mathrm{N}$ through increased soil microbial activity (Kucey et al., 1988; Ladha et al, 1989; Wani et al., $1991 \mathrm{a}, \mathrm{b}$ ). A two fold increased microbial biomass $C$, in the AER soil than in the CG soil was observed. The concentration of microbial $\mathrm{N} \mathrm{g}^{-1}$ soil; the proportions of soil $\mathrm{N}$, or the proportion of soil ${ }^{15} \mathrm{~N}$ present as microbial $\mathrm{N}$, and microbial activity as indicated by the respiration rate, were all greater in the agroecosystem than in the CG system (Wani et al. 1991a). These results indicated that higher proportion of soil or fertilizer $N$ was in the labile fraction in the case of AER than in the case of the CG system. Wani et al., (1991b) observed that in an eight year agro-ecological rotation containing fababeans and forage, mycorrhizal colonization of barley roots was increased as compared to a CG system. Further, through positive relationships 
between levels of mycorrhizal colonization and $\mathrm{K}, \mathrm{Ca}$, $\mathrm{Mg}, \mathrm{Zn}_{*} \mathrm{~S}$, and $\mathrm{Fe}$ accumulations and barley yields it was inferred that increased mycorrhizae acted as agents to mediate enhanced soil fertility in the rotations over that of a continuous barley system.

Improvements in the soil structure following legumes, mainly improved soil aggregate formation, after three years of alfalfa, clover and hairy vetch mixture (Latif et al., 1992) or with numerous years of a Sod pasture, or hay crop (Olmstad, 1947; Power, 1990; Strickling, 1950) have been observed. Incorporation of legume residues improved soil water-holding (Wani et al., 1994c) and buffering capacity (Buresh and De Datta, 1991).

Ries at al. (1977) suggested that growth promoting substances in legume residues are responsible for the rotation effect. The rotations break the cycles of cereal pests and diseases, and phytotoxic and allelopathic effects of different crop residues (Francis et al, 1986). The effect of crop rotation on pest pressure varies widely, but in general the literature supports Francis and Clegg (1990) who stated that "the greater the differences between crops in a rotation sequence, the better cultural control of pests can be expected". Crop rotation is an effective tool against certain pests, and that efficacy may contribute to the rotation effect, but rotation does not control all pests and diseases. For example, Johanson et al. (1984) reported that black cutworms (Agrotis ipsilon) are more of a problem when maize is rotated with either soybean or wheat than when maize is grown continuously. Similarly, Want et al., (1991b) observed no reduction in the common root rot (Bipolaris sorokiniana) of barley grown in rotation plots than the continuous barley plots. On the contrary, marginally higher root rot incidence was recorded from the eight year rotation plots containing fababeans and forages.

\section{Ways to improve BNF in the SAT}

\section{Host-related aspects}

\section{Host variability for nodulation and nitrogen fixation}

Presence of a large genotypic variability for BNF traits like nodule number, nodule mass and acetylene rcduction activity (ARA) per plant has been known since early eighties for chickpea, groundnut and pigeonpea (Nambiar et al., 1988), soybean (Wacek and Brill,
1976), cowpea (Zari et al., 1978), common bean (Graham and Rosas, 1977). Using ${ }^{15} \mathrm{~N}$ isotope-based methods, differences among cultivars have been detected in soybean (Hardarson et al., 1989; Rennie et al., 1982), common bean (Rennie and Kemp, 1982; Westernann et al., 1981), groundnut (Giller et al., 1987), greengram and blackgram (Sampet and Peoples, unpubl. data cited by Peoples and Crasswell, 1992), pigeonpea (I V D K Kumar Rao, pers. commun.) and chickpea (Rupela et al., unpubl, data). However, efforts to use this variability in breeding for improved BNF has been limited or non existent in many of these legumes. Arunachalam et al. (1984) found that ARA and nodule mass have good predictive value for plant growth and yield related traits in groundnut. After analysis of a six parent diallel cross, Nigam et al. (1985) observed that nonadditive genetic variance for ARA was predominant in groundnut. The groundnut line NC Ac 2821 had the highest general combining ability for ARA, tota nitrogen, leaf area and was proposed as a good parent for breeding programs. The crosses made between the high-and low-nodulating chickpea lines to investigate the inheritance of nodulation indicated segregation for nodulation in $F_{2}$ populations from nonnodulating to nodulating (O P Rupela, unpubl.). These studies thus indicate the complexity of the BNF related traits. Most of the studies reported above for chickpea and groundnut were made in the field. Legumes like pigeonpea offer another difficulty for BNF studies because their nodules are loosely attached to roots and generally fall off during excavation of the field grown plants. It is perhaps due to this reason that there are no reports in pigeonpea so far on studies of the type reported above for groundnut.

Indication of plant to plant variability for nodulation within chickpea cultivars was further investigated. It was observed that not only consistent low- and high-nodulating plants were present within chickpe: cultivars (Rupela, 1994), even nonnodulating plants occurred in normal cultivars or land races (Rupela, 1992). Consistent variability for nodulation extent was also subsequently detected. within the pigeonpea cultivars. Unlike in chickpea, however, nonnodulating plants in pigeonpea were found in segregating populations at $F_{2}$ (Rupela and Johansen, 1995). It is perhaps due to the absence of any natural selection pressure for nodulation or BNF during development of a cultivar that the different nodulation types continue to exist within a material up to release stage. This gained strength from the fact that during a screening for highnodulating plants at high mineral $\mathrm{N}$ in soil, we observed 
Table 7. Different nodulation types of chickpea and pigeonpea plants identified at ICRISAT Center, India

Chickpea

- Nonnodulating with native root nodulating bacteria (RNB) (m6)

- Nonnodulating with IC 59, low nodulating with native RNB

- Low nodulating at low $\mathrm{N}$

- High nodulating at low $\mathrm{N}$

- High nodulating at low $\mathrm{N}$ but low nodulating at high $\mathrm{N}$

- High nodulating at high $\mathrm{N}$

Pigeonpea

- Nonnodulating with native RNB

- Low nodulating at low $\mathrm{N}$

- High nodulating at low $\mathrm{N}$

Parenthesis has the name of the identified gene.

Source: Rupela (1994).

the desired plants in 85 out of 90 advanced breeding lines of chickpea that were studied (Rupela, 1994).

Using appropriate screening procedures several different nodulation types have been identified within several chickpea and pigeonpea cultivars (Table 7) since 1985. Preliminary studies of Venkateswarlu and Katyal (1994) also indicated plant to plant variability within cultivars of groundnut. Intracultivaral variability for nodulation may be present in other legumes also. Obviously the $\mathrm{Nod}^{-}(\mathrm{NN})$ and the low-nodulating (LN) selections are of academic interest and serve as an important reference base in BNF quantification studies. High-nodulating (HN) selections are expected to improve yield in low soil $\mathrm{N}$ conditions. In our screening studies the HN selection generally grew better than the NN and LN selections of a given cultivar, but large plot yield trials have been conducted only with the LN and HN chickpea selections of ICC 4948 and ICC 5003. The HN-selection of cultivar ICC 4948 produced $31 \%$ more grains than its LN-selection at low soil N(N1) level (Fig. 4). The HN-selection of ICC 4948 yielded better even at high soil N(N2) level. But the LN and HN selections of another cultivar ICC 5003 yielded the same under $\mathrm{N} 1$ and $\mathrm{N} 2$ levels. In a previous pot trial the root length density of LN-ICC 5003 was $32 \mathrm{~m}_{\text {plant }}^{-1}$ which was 2-times greater than that of the LN-ICC 4948. Perhaps the cultivar ICC 5003 could scavenge the soil N more efficiently than that of ICC 4948 due to its high root length density and as a result both the $\mathrm{HN}$ and LN lines of ICC 5003 yielded similarly.

These studies thus suggest a great scope for enhancing BNF in legumes through host plant selection. Most
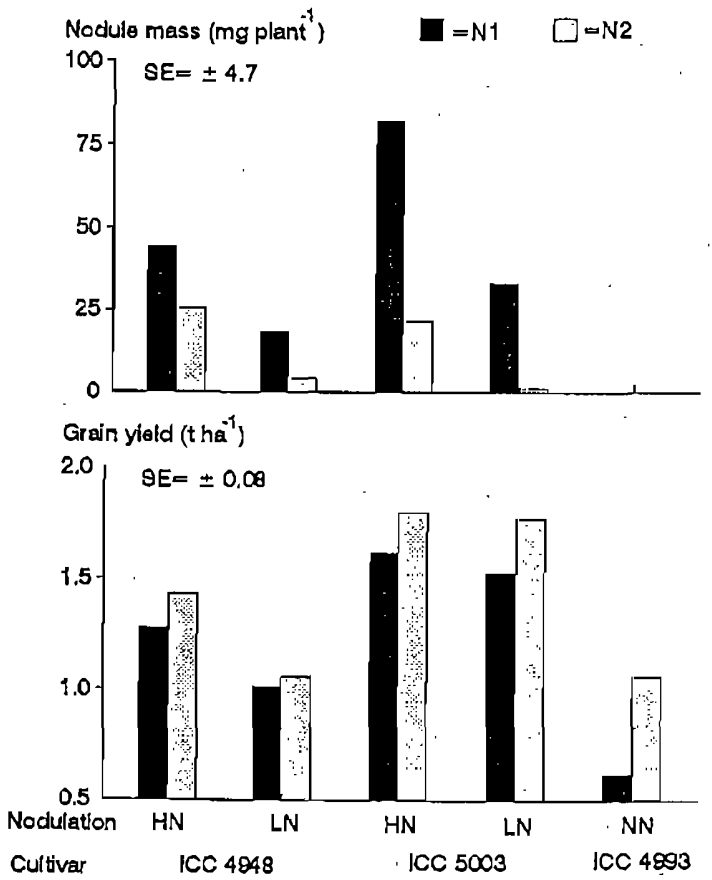

Fig. 4. Nodule mass at 45 days after sowing and grain yield of chickpea cultivars of different nodulation ratings ( $\mathrm{HN}=$ high nodulating, $\mathrm{LN}=$ low nodulating, $\mathrm{NN}=$ nonnodulating; grown at two mineral $\mathrm{N}$ levels in soil low $\mathrm{N}\left(\mathrm{N} 1\right.$, about $10 \mathrm{mg} \mathrm{kg}^{-1}$ soil) and high $\mathrm{N}$ (N2, about $20 \mathrm{mg} \mathrm{kg}^{-1}$ soil); postrainy season, 1991/92, Vertisol, ICRISAT. Both N-levels and nodulation were significantly different $(p=0.05)$ for the above parameters. Their interactions were also significantly different for nodule mass. Source: Rupela, (unpubl.).

HN selections yielded higher than the LN selections (Fig. 4 and unpubl. studies). However, it needs to be established in further studies.

\section{Breeding for increased $B N F$ and nitrate tolerance}

Soybean cv. Dunadja from Romania showed no reduction in $\mathrm{N}_{2}$-fixation with application of $100 \mathrm{~kg} \mathrm{~N} \mathrm{ha}^{-1}$ while in all the other seven cultivars $\mathrm{N}_{2}$ fixation was substantially reduced (Hardarson et al., 1989). Similarly soybean cultivars of Korean origin with higher $\mathrm{N}_{2}$-fixation than the commercial cultivars grown in Australia have been identified and used as donor parents in a breeding program in Australia (Betts and Herridge, 1987; Peoples and Herridge, 1990). Plant mutagenesis has been used to generate $\mathrm{NO}_{3}$ tolerant $\mathrm{N}_{2}$-fixing phenotypes e.g. nitrate-tolerant symbiont in soybean (Carroll et al., 1985). Extreme super nodulating mutants of soybean and Phaseolus vulgaris produced significantly lower biomass and/or grain yield than their parent lines (Buttery et al., 1990; Hansen et 
Table 8. Response of chickpea, pigeonpea and groundnut to fertilizer nitrogen in experiments on farmers' fields in India

\begin{tabular}{|c|c|c|c|c|c|c|}
\hline \multirow[b]{2}{*}{ State } & \multicolumn{2}{|c|}{ Chickpea } & \multicolumn{2}{|c|}{ Pigeonpea } & \multicolumn{2}{|c|}{ Groundnut } \\
\hline & $\begin{array}{l}\text { No. of } \\
\text { trials }\end{array}$ & $\begin{array}{l}\mathrm{kg} \text { grain } \\
\mathrm{kg}^{-1} \mathrm{~N}\end{array}$ & $\begin{array}{l}\text { No. of } \\
\text { trials }\end{array}$ & $\begin{array}{l}\mathrm{kg} \text { grain } \\
\mathrm{kg}^{-1} \mathrm{~N}\end{array}$ & $\begin{array}{l}\text { No. of } \\
\text { trials }\end{array}$ & $\begin{array}{l}\mathrm{kg} \text { grain } \\
\mathrm{kg}^{-1} \mathrm{~N}\end{array}$ \\
\hline Andhra Pradesh & 47 & 16.5 & 56 & 17.5 & 258 & 18.0 \\
\hline Bihar & 77 & 17.0 & $-a$ & - & 25 & 25.0 \\
\hline Gujarat & - & - & 159 & 15.5 & - & - \\
\hline Haryana & 88 & 12.0 & - & - & - & - \\
\hline Himachal Pradesh & 50 & 11.0 & - & - & - & - \\
\hline Karnataka & 275 & 11.0 & 104 & 8.0 & 310 & 14.5 \\
\hline Madhya Pradesh & 624 & 19.0 & 15 & 10.5 & - & - \\
\hline Maharashtra & 351 & 8.5 & - & - & 495 & 12.0 \\
\hline Orissu & 71 & 8.5 & 39 & 19.0 & - & - \\
\hline Punjab & 113 & 10.5 & - & - & 62 & 17.0 \\
\hline Rajasthan & 267 & 18.0 & 159 & 13.0 & 38 & 12.5 \\
\hline Tamil Nadu & - & - & - & - & 384 & $\$ 4,0$ \\
\hline Uttar Pradesh & 408 & 21.5 & - & - & 14 & 12.0 \\
\hline Average & & 15.4 & & 14.2 & & 14.4 \\
\hline
\end{tabular}

${ }^{a}$ Not conducted.

Source: Tandon (1992)

al., 1989; Wu and Harper, 1991). Species differ considerably in their symbiotic tolerance to mineral $\mathrm{N}$ and when sufficient natural variation already exists (Betts and Herridge, 1987; Hardarson et al., 1984) it may not be necessary to resort to mutagenesis procedures for breeding purposes (Gibson and Harper, 1985).

\section{Management practices}

\section{Nitrogen}

Most of the legumes cannot derive $100 \%$ of their $\mathrm{N}$ requirement through BNF. In the tropics where legume residues are not returned to the soil, most legumes deplete the soil $\mathrm{N}$ (Table 2 and 3 ). In the long run, such systems cannot be sustainable. Further, large numbers of on-farm experiments in India showed that legumes responded markedly to fertilizer $\mathrm{N}$; such responses are expected as legumes have a high $\mathrm{N}$ requirement. The SAT soils are poor in $\mathrm{N}, \mathrm{N}_{2}$-fixation mechanisms do not become functional from day one and all the legume requirement cannot be met from BNF. Significant responses to $20-30 \mathrm{~kg} \mathrm{~N}^{-1}$ as starter have been observed under good growth conditions (Table 8). At application rates of $20 \mathrm{~kg} \mathrm{~N} \mathrm{ha}^{-1}$, overall response rate (grain $\mathrm{kg}^{-1} \mathrm{~N}$ ) was 14.2 in pigeonpea, 14.4 in groundnut and 15.4 in chickpea all under non-irrigated conditions (Table 8). Responses of such high magnitude point that to achieve increased legumes productiv- ity along with increased BNF and maintaining the soil fertility, we need to adopt need-based mineral $\mathrm{N}$ application to legumes. Soil mineral $\mathrm{N}$ status at the time of sowing of the legume crop must be taken into account before deciding on the need and rate of $\mathrm{N}$ fertilizer application.

In general, high soil nitrogen levels, applied or residual, reduces nodulation and $\mathrm{N}_{2}$ fixation (Tables 9 and 10). To improve BNF contribution from the legumes under such circumstances soil $\mathrm{N}$ must be managed through inclusion of appropriate nitrate tolerant high $\mathrm{N}_{2}$-fixing legume crop or genotype of a given crop as mentioned earlier and/or appropriate cropping and management practices. It has been observed that application of $200 \mathrm{~kg} \mathrm{~N}^{-1}$ decreased $\mathrm{N}_{2}$ fixation by groundnut only by $18 \%$ (from $120-102 \mathrm{~kg} \mathrm{ha}^{-1}$ ) whereas in cowpea by $54 \%$ (from 125 to $57 \mathrm{~kg} \mathrm{ha}^{-1}$ ) (Yoneyama et al., 1990). These results suggest that there exists a potential to select appropriate legume crops or cultivars of a given legume for specific areas with high soil $\mathrm{N}$ contents without decreasing their BNF contribution to the system.

\section{Intercropping}

Legumes are generally grown as intercrops with cereals or other non-legumes in the SAT (Willey, 1979) and application of $\mathrm{N}$ to the cereal crop reduced $\mathrm{N}_{2}$ fixation by the component legume crop (Nambiar et 
Table 9. Nitrogen concentrations in root environment where approximately $50 \%$ reduction in $\mathrm{N}_{2}-$ fixation was recorded

\begin{tabular}{|c|c|c|c|c|c|}
\hline $\begin{array}{l}\text { Suppressive } \\
\text { concentration } \\
\text { (in reference) }^{a}\end{array}$ & $\begin{array}{l}\text { ppm } \\
\text { equiv. }\end{array}$ & BNF as & Crop & $\begin{array}{l}\text { Plant } \\
\text { culture }\end{array}$ & Reference \\
\hline $1.43 \mathrm{mM}$ & 20 & Nodule no. & Chickpea & Pot & Rawsthorne et al. (1985) \\
\hline $6 \mathrm{mM}$ & 84 & Nod mass, ARA & Soybean & Pot & Buttery and Dirks (1987) \\
\hline $2 \mathrm{~mol} \mathrm{~m}^{-3}$ & 28 & ${ }^{15} \mathrm{~N}$ & Chickpea, Fababean & Pot & Peoples et al. (1987) \\
\hline $5 \mathrm{mM}$ & 70 & ARA & Chickpea & Pot & Sawhney et al. (1989) \\
\hline $200 \mathrm{~kg} \mathrm{ha}^{-1}$ & 89 & ARA & Soybean & Field & Wu and Harper (1991) \\
\hline $112 \mathrm{~kg} \mathrm{ha}^{-1}$ & 50 & Nod mass & Pigeonpea, Soybean & Field & Buttery et al. (1988) \\
\hline $3 \mathrm{~m} M$ & 42 & Nod mass, ARA & Common bean & Pot & Buttery et al. (1990) \\
\hline $112 \mathrm{~kg} \mathrm{ha}^{-1}$ & 50 & Nod mass & Common bean & Field & Buttery et al. (1990) \\
\hline $10 \mathrm{mM}$ & 140 & Nod mass, ARA & Fababean & Field & Buttery and Gibson (1990) \\
\hline $5 \mathrm{mM}$ & 70 & Nod mass & Soybean & Pot & Cho and Harper (1991) \\
\hline
\end{tabular}

${ }^{a}$ In all cases, except for Rawsthorne et al. (1985), the listed nitrate concentration was the lowest level used in different trials.

al., 1983; Ofori and Stern, 1987). Similarly, shading by associated cereals reduced BNF in the component legumes (Nambiar et al., 1983; Wahua and Miller, 1978). Strip cropping of the cereals and legumes can overcome both these problems and improve the systems productivity without reducing BNF contributions in the system from the associated legumes. Indeterminate legumes fix more $\mathrm{N}$ than determinate types in intercropping (Fugita et al., 1992). Nitrogen fixation in climbing bean (Francis, 1986; Graham and Rosas, 1978), cowpea (Ofori et al., 1987) and Siratro (Ogata et al., 1986) was unaffected by intercropping with cereals. In cases where strip cropping is not possible, climbing type legumes can be used.

\section{Tillage}

Nodulation and $\mathrm{N}_{2}$ fixation in soybean grown in subtropical Australia were substantially improved under Io tillage with $\mathrm{N}$ balance of $80 \mathrm{~kg} \mathrm{~N} \mathrm{ha}^{-1}$, compared with the cultivated system with $30 \mathrm{~kg} \mathrm{~N}^{-1} \mathrm{~N}$ balance. Increased $\mathrm{N}_{2}$ fixation resulted mainly from the higher proportion of plant $\mathrm{N}$ derived from fixation since yields were unaffected by tillage practice (Peoples and Crasswell, 1992). Clean cultivation accelerates the oxidation of organic matter in soils and generally results in higher $\mathrm{NO}_{3}$ in the profile (George et al., 1992; Thomas et al., 1973) which would affect BNF in legumes.

\section{Land form}

Greengram, pigeonpea and soybean grown on broad bed and furrows (BBF) on Vertisol improved nodulation than when grown on a flat surface. However, improved nitrogenase activity on BBF was recorded with greengram and pigeonpea only (Wani and Potdar, unpubl. data). However, in Vertisols, chickpeas sown on flat beds nodulated better than those sown on ridges with the same sowing density (Rupela and Saxena, 1987). As the ridged fields had greater evaporation losses due to increased surface area; this may be important when moisture is limiting.

\section{Deep sowing}

Deep sowing of groundnut results in the development of an elongated hypocotyl, poor rooting, poor nodulation and nitrogen fixation, notably in spanish types. Virginia types have considerable nitrogenase activity even when sown deep because of their ability to nodulate on the hypocotyl (Nambiar et al., 1988). Farmers tend to sow chickpea at a sufficient depth to ensure good crop stand as it is generally grown on residual moisture. Deep sown chickpea crops in heavy black soils suffer a substantial reduction in nodulation and $\mathrm{N}_{2}$ fixation. In lighter soils chickpea have been found to nodulate at depth (Rupela et al., 1985).

\section{Other nutrients}

It should be realized however, that poor $\mathrm{N}_{2}$ fixation can be due to poor plant growth resulting from pests, diseases, and nutrient deficiencies. Addition of P stimulated pigeonpea nodulation in both an Alfisol and a Vertisol (Kumar Rao and Dart, 1981). In Karnataka, India, trials on farmer's fields with pigeonpea showed increased nodulation due to application of diammonium phosphate (DAP) alone than to the inoculation with 
Table 10. Effect of soil mineral $\mathrm{N}$ and $\mathrm{N}$ fertilizers on crop $\mathrm{N}$ productivity and the proportion $(\mathrm{P})$ and amount of crop $\mathrm{N}$ derived from $\mathrm{N}_{2}$ fixation

\begin{tabular}{|c|c|c|c|c|c|c|c|}
\hline \multirow[t]{2}{*}{ Species } & \multirow[t]{2}{*}{ Location } & \multicolumn{2}{|l|}{ Level } & \multirow{2}{*}{$\begin{array}{l}\text { Total } \\
\text { crop } N \\
\left(\operatorname{kg} N \mathrm{ha}^{-1}\right)\end{array}$} & \multicolumn{2}{|c|}{$\mathrm{N}_{2}$ fixed } & \multirow[t]{2}{*}{ Reference } \\
\hline & & $\begin{array}{l}\text { Soil } \\
\text { mineral } \mathrm{N} \\
\left(\mathrm{kg} \mathrm{N} \mathrm{ha}^{-1}\right)\end{array}$ & $\begin{array}{l}\text { Fertilizer } \\
\mathrm{N} \\
\left(\mathrm{kg} \mathrm{N} \mathrm{ha}^{-1}\right)\end{array}$ & & $\mathrm{P}$ & $\begin{array}{l}\text { Amount } \\
\left(\mathrm{kg} \mathrm{N} \mathrm{ha}^{-1}\right. \\
\left.\text { crop }^{-1}\right)\end{array}$ & \\
\hline \multirow[t]{3}{*}{ Groundnut } & India & - & 0 & 196 & 0.61 & 120 & Yoneyama et al. (1990) \\
\hline & & & 100 & 210 & 0.47 & 99 & \\
\hline & & & 200 & 243 & 0.42 & 102 & \\
\hline \multirow[t]{5}{*}{ Chickpea } & Australia & $10($ to $120 \mathrm{~cm})$ & & 114 & 0.85 & 97 & Doughton et al. (1993) \\
\hline & & 326 & & 194 & 0.17 & 33 & \\
\hline & & & 0 & 97 & 0.81 & 79 & \\
\hline & & & 50 & 114 & 0.59 & 59 & Herridge et al. (1994 \\
\hline & & & 100 & 115 & 0.29 & 25 & \\
\hline \multirow[t]{9}{*}{ Soybean } & Australia & $70($ to $120 \mathrm{~cm})$ & & 230 & 0.34 & 78 & Herridge et al. (1990) \\
\hline & & 260 & & 265 & 0.06 & 16 & $i$ \\
\hline & India & - & $0^{a}$ & 63 & 0.29 & 18 & Yoneyama et al. (1990) \\
\hline & & & 100 & 108 & 0.26 & 28 & \\
\hline & & - & $0^{b}$ & 89 & 0.48 & 43 & \\
\hline & & & 100 & 115 & 0.24 & 28 & \\
\hline & Malaysia & - & 40 at sowing & 169 & 0.68 & 115 & Norhayati et al. (1988) \\
\hline & & day $45+$ further or & 20 as nitrate & & & & \\
\hline & & & 20 as urea & 200 & 0.15 & 30 & \\
\hline \multirow[t]{2}{*}{ Common bean } & Kenya & - & 10 & 149 & 0.39 & 58 & Ssali and Keya (1986) \\
\hline & & & 100 & 158 & 0.10 & 16 & \\
\hline \multirow[t]{5}{*}{ Cowpea } & Kenya & - & 20 & 116 & 0.53 & 62 & Ssali and Keya (1984) \\
\hline & & & 100 & 137 & 0.08 & 11 & \\
\hline & India & - & 0 & 163 & 0.77 & 125 & Yoneyama et al. (1990) \\
\hline & & & 100 & 138 & 0.67 & 92 & \\
\hline & & & 200 & 172 & 0.33 & 57 & \\
\hline
\end{tabular}

${ }^{a}$ Uninoculated.

${ }^{\text {bInoculated. }}$

Rhizobium alone (Chinmulgund and Hegde, 1987). Cassman et al. (1981) found that field-grown soybean had a higher $\mathrm{P}$ requirement when it was dependent on BNF for its $\mathrm{N}$ supply as compared to the mineral $N$ dependency. Based on the results from 140 onfarm demonstration plots with soybean in Uganda it was observed that on an average $300 \mathrm{~kg} \mathrm{ha}^{-1}$ yield increase was obtained with $40 \mathrm{~kg} \mathrm{P}_{2} \mathrm{O}_{5} \mathrm{ha}^{-1}$ application and further increase of $300 \mathrm{~kg} \mathrm{ha}^{-1}$ was obtained through inoculation with Rhizobium (Keyser and $\mathrm{Li}$, 1992).

In groundnut, fertilization with $\mathrm{B}, \mathrm{Co}, \mathrm{Mo}$ and $\mathrm{Zn}$ in a medium calcareous soil, with and without $R h i$ zobium inoculation significantly increased nodulation, percentage of effective nodules and plant dry mat ter (Joshi et al., 1987). It has been reported that $\mathrm{Fe}$ deficiency specifically limits nodule development in groundnut grown in the calcareous soils of Thailand (O'Hara et al., 1988). Soil acidity along with $\mathrm{Mn}$ and Al toxicities can also restrict $\mathrm{N}_{2}$ fixation in groundnut. Excess $\mathrm{Mn}$ was detrimental to plant growth per se rather than to nodulation, but nitrogenase activity was more affected by $\mathrm{Al}$ than plant growth (Nambiar and Anjaiah, 1989a). Application of $\mathrm{Co}$ at a rate of $500 \mathrm{mg}$ cobalt nitrate $\mathrm{kg}^{-1}$ seed significantly increased grain yield of pigeonpea (Raj, 1987), soil application of $0.45 \mathrm{~kg} \mathrm{Mo} \mathrm{ha}^{-1}$ as sodium molybdate significantly increased nodulation and grain yield of pigeonpea 


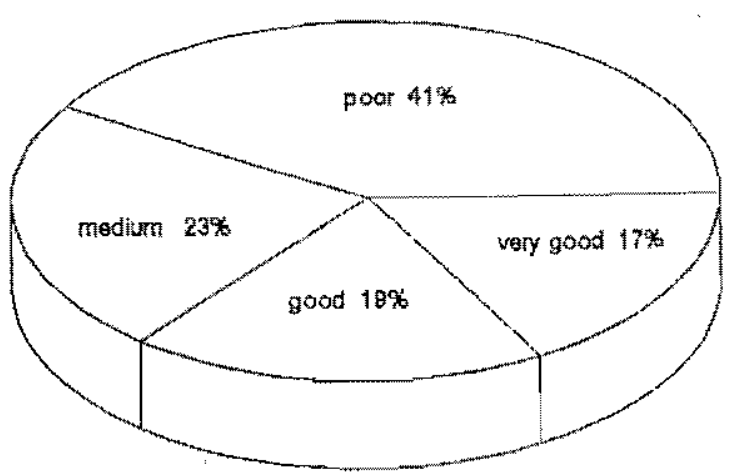

Fig. 5. Nodulation status of chickpea based on 314 fields. (AICPIP data cited by Tauro and Khurana, 1986).

(Khurana and Dudeja, 1981). Soil application of $1 \mathrm{~kg}$ cobalt chloride, $1 \mathrm{~kg}$ sodium molybdate $\mathrm{ha}^{-1}$ and 25 $\mathrm{kg} \mathrm{ZnSO}_{4} \mathrm{ha}^{-1}$ increased chickpea grain yield by 10 , 7 and $4 \%$ respectively over the control. Inoculation with Rhizobium increased chickpea yield by $26 \%$ over the non-inoculated control however, inoculation along with $\mathrm{Co}, \mathrm{Mo}$ and $\mathrm{Zn}$ application increased yield by $4 \mathrm{I}$, 39 and $28 \%$ respectively over the control (Nandeo and Gupta, 1992).

\section{Insects}

Extensive nodule damage to pigeonpea by a Dipteran larva, Rivellia angulata was reported in farmers'. fields (Sithanantham et al., 1981). The extent of nodule damage was greater in pigeonpea grown in Vertisols (up to 86\%) as compared to $20 \%$ in Alfisols (Nambiar et al., 1988). Nambiar et al. (1990) reported reduced nodule damage by $50 \%$ due to inoculation of pigeonpea with engineered Bradyrhizobitum carrying an insecticide gene (Bacillus thuringiensis subsp. israelensis) in the presence of Rivellia angulata larvae under greenhouse conditions. These results suggest the potential benefits from planned introduction of engineered Bradyrhizobia carrying insecticide genes into natural environments. Another possible solution is to select pigeonpea genotypes that can resist or tolerate attack by nodule damaging insects. Soil application of a single dose of insecticide (aldrin) prevented nodule damage up to 45 DAS however, during later stages insect damage could not be controlled (Kumar Rao and Sithanantham, 1989).

\section{Use of inoculants}

Much of the applied research efforts in studying BNF have gone into identifying efficient strains of bacte- ria as inoculants. Before inoculation with appropriate strains to be used, it needs to be determined whether inoculation is needed?

\section{Need for inoculation}

The most important point is do we need inoculation of the legumes in a region where these crops have been grown over long periods? Development of an inoculation industry in many countries has been largely motivated by the desire to introduce legume species to new areas (Burton, 1982). Most cultivated tropical soils are assumed to have relatively large populations (> $100 \mathrm{~g}^{-1}$ dry soil) of rhizobia capable of nodulating the legumes grown in such soils (Nambiar et al, 1988). However, surveys of farmers' grain and fodder legume crops have shown poor nodulation in large areas and good nodulation only in a few pockets (Fig. 5) (IARI, 1980; Kabi and Poi, 1988; Kulkarni and Joshi, 1988; Tauro and Khurana, 1986). In a survey of farmers ${ }^{*}$ chickpea fields around Gwalior, Madhya Pradesh (M.P.), 39\% fields had $<100$ rhizobia $\mathrm{g}^{-1}$ soil, $17 \%$ had $10^{2}-10^{3}$ and $44 \%$ fields had a population $>10^{3}$ (Rupela et al. 1987). In a similar survey conducted for $43-47$ villages from each of the three districts of Madhya Pradesh, India for nodulation of pigeonpea, black gram, green gram and lentil showed poor nodulation $\left(0-10\right.$ nodules plant $\left.{ }^{-1}\right)$ in 64 to $100 \%$ of the surveyed area (Namdeo and Gupta, 1992). The need to inoculate the legumes grown on cultivated soils must be assessed by considering the interacting factors between the soil, the host plant and Rhizobium.

Presence of nodules on plant roots does not necessarily mean that sufficient $\mathrm{N}_{2}$ is being fixed for maximum benefit to the host plant. In groundnut or pigeonpea nodulation occurs naturally at most locations due to the cross-species promiscuity of the cowpea rhizobia. However, the ability to fix high amounts of $\mathrm{N}$ (efficiency) is governed by the symbiotic capability between Rhizobium and the host plant. Hence, it may be necessary to introduce superior (more competitive and efficient) strains of Rhizobium to ensure adequate $\mathrm{N}_{2}$ fixation for maximum growth and yield of the host plant. In a survey of groundnut crops grown in farmers ${ }^{x}$ fields in southern India, $\$ 2$ out of 95 fields showed inadequate nodulation with less than 10 per cent ARA of that which can be obtained under reasonable field conditions (Nambiar et al.; 1982). Although, adequate nodulation was observed in some parts, ineffective nodules exceeded the number of effective nodules. Field surveys have shown that proportion of inef- 
fective strains was as high as $40 \%$ in chickpea, $53 \%$ in green gram and $63 \%$ in groundnut (Tauro and Khurana, 1986). In another study $94 \%$ strains of rhizobia were observed ineffective in groundnut (Kulkarni and Joshi, 1988). Poor nodulation in farmers' fields could be due to several factors e.g. inadequate soil moisture, lack of appropriate rhizobia in soil, deficiency or toxicity of a particular nutrient, unfavorable conditions like prolonged water logging, unfavorable $\mathrm{pH}$, abundance of bacterial predators, pests and disease attack, etc.

Using the network approach NifTAL initiated Worldwide Rhizobial Ecology Network (WREN) and conducted standardized inoculation trials with extensive environmental data. Thies et al. (1991) developed a mathematical model using native rhizobia numbers (estimated by most probable number method) and soil mineral $\mathrm{N}$ data as inputs to predict the inoculation responses at different sites. This approach accounted for $83 \%$ of the variation observed due to inoculation. These models have been incorporated into an interactive computer program called "RESPONSE" which reduces the need for costly, site-specific field inoculation trials to determine the need for inoculation with Rhizobium. This remains a valid approach to determine the need for inoculation in most of the cases. However, Nambiar (1985) reported significant yield increases from Cameroon, India, and China in the case of groundnut due to inoculation with NC 92 strain from the soils having large populations of native rhizobia. These results indicate that a simulation model using most probable number (MPN) data and mineral $\mathrm{N}$ data can not provide reliable answers in all the cases and there is a need to fine-tune the model.

\section{Compatitive and effective strains}

In soils lacking rhizobia nodulating a particular legume, inoculation with efficient strains increased yields (Nambiar et al, 1988). In soils which contain established native Rhizobium populations, the introduced strains should be competitive and efficient. The degree of establishment and persistence of an inoculant strain generally decreased with increase in population density of the native rhizobia (ICRISAT, 1981). However, some inoculant strains have succeded in forming more nodules even in the presence of active indigenous competing rhizobia eg. NC 92 on groundnut (Nambiar et al., 1984). Little is known of the factors controlling competitiveness but host cultivar, soil properties, soil microflora, environmental factors and the nature of the competing strains influence the success of inoc- ulant strains in nodule formation (Alexander, 1982). The suceess of the strain NC 92 in terms of nodule formation increased with repeated inoculation (Table 11). Higher inoculum rate of $10^{6}-10^{8}$ cells per seed at the initial inoculation helped in early establishment (Nambiar et al,, 1984). Strains of vesicular arbuscular mycorrhizae (VAM) significantly influenced nodule formation by bradyrhizobia strains. In the absence of any VAM, when mixtures of NC 92 and NC 43.3 were inoculated, strain NC 92 occupied more nodules $(89 \%)$ than strain NC $43.3(34 \%)$. In the presence of Acaulospora laevis, $86 \%$ nodules in the $\mathrm{NC} 92+\mathrm{NC}$ 43.3 mixture were formed by NC 92 , but the presence of Glomus fasiculatus reduced the competitive ability of strain NC 92 (49\% NC 92 nodules) (Nambiar and Anjaiah, 1989b). Field trials with soybean have demonstrated that to achieve nodule occupancy of greater than $50 \%$, inoculant rhizobia/bradyrhizobia must be applied at a rate at least 1,000 times greatel than the estimated number of indigenous bradyrhizobia in soil (Weaver and Frederick, 1974). Competition between inoculated and native Rhizobium strains and response to inoculation was less pronounced in the presence of soil mineral $\mathrm{N}$ than under conditions where such $N$ was immobilized and made unavailable (Somasegaran and Bohlool, 1990). Use of massive inoculation rates can overcome competition from indigenous strains (Kapusta and Rouwenhorst, 1973), but such a delivery system is not yet economical and practical.

In many rice-growing areas, legumes are grown after paddy, using residual moisture. In such fields, less than 100 cowpea group rhizobia $\mathrm{g}^{-1}$ soil were observed and continuous cultivation of paddy had an adverse effect on Rhizobium survival. Under such conditions inoculation with effective strains showed significant responses in chickpea and pigeonpea (Nambiar et al., 1988).

\section{Factors affecting performance of inoculant strains}

Crop responses to inoculation with biofertilisers are not as visible as those with fertilizer N. Being biological agents, these are subjected to a range of hostile environments and their survival and efficiency is governed by several factors. Generally, there is a decline in the rhizobial population on seeds but conventional wisdom is that multiplication should occur as the rhizosphere forms, so that accelerated germination can also assist in ensuring an adequate population. The seed coat of a dicot is often carried on the top of the cotyledons into 
Table 11. Persistence of inoculum struin NCS2 over two seasons on groundnut

\begin{tabular}{|c|c|c|c|}
\hline \multicolumn{2}{|l|}{ Season } & \multicolumn{2}{|c|}{ \% nodules formed on groundnut plants } \\
\hline lst & 2nd & 72 days after sowing & 116 days after sowing \\
\hline Uninoculated & Unünoculated & $9(5)^{a}$ & $11(8)$ \\
\hline Uninoculated & Inoculated & $31(27)$ & $27(25)$ \\
\hline Inoculated & Uninoculated & $28(25)$ & $42(32)$ \\
\hline Inoculated & Inoculated & $39(41)$ & $75(54)$ \\
\hline $\mathrm{SE}$ & & \pm 2.5 & \pm 5.4 \\
\hline
\end{tabular}

a Data analysed after arsine transformation: original means in parenthesis.

Source: Nambiar (1985).

the open air, so that only a part of the inoculum may be left to multiply within the rhizosphere. In the case of crops grown on residual moisture, such as chickpea, the inoculated thizobia cannot move downwards yith the growing root from the top soil where inoculated, resulting in poor nodulation. Secondly, deep sowing results in a good crop stand but affects nodulation adversely (Nambiar et al., 1988).

Carrier-based inoculants are usually coated on seeds for the introduction of bacterial strains into the soil. However, alternative inoculation methods are necessary where seed treatment with fungicides and insecticides is needed or where seed of crops such as groundnut and soybean can be damaged when inoculated with an adhesive. In addition, use of superphosphate as the P source can be harmful for Rhizobium because of contact, with the acidic fertilizer. Often the soils themselves are acidic and lime coating of seed has been a popular measure for additional protection. The normal carrier-based inocula can be successfully applied separately from the seed (Bonnier, 1960; Burton, 1982). While all methods of inoculation were successful under favorable conditions, "liquid" and "sol-

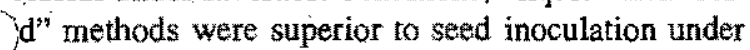
adverse conditions (Brockwell et al., 1980). Increased groundnut yields were obtained when inoculation was done by applying a slurry of peat-based inoculum in the seed furrow (Table 12). At ICRISAT, a bullockdrawn seed drill commonly used by farmers has been modified for simultaneous Rhizobium application in the seed furrow (Nambiar, 1985).

Soil properties can also affect the survival of inoculated rhizobia. For example, out of 11 locations tested for response of groundnut $\mathrm{cv}$, Robut 33-1, inoculation with strain NC 92 failed to increase yields at two locations, namely Tirupathi and Kadiri, India (AICORPO, 1983). Subsequent analysis of soil samples from Tiru- pathi revealed a high $\left(150 \mathrm{mg} \mathrm{kg}^{-1}\right)$ available manganese content (Nambiar, 1985). Manganese and aluminum can be toxic to symbiotic $\mathrm{N}_{2}$ fixation even if they are not at a level high enough to affect plant growth (Franco, 1977). Soil acidity and alkalinity can also pose problems for symbiotic $\mathrm{N}_{2}$ fixation. For such problem areas, specific strains with the ability to overcome such adverse conditions need to be selected as inoculants. Significant differences were observed among pigeonpea rhizobial strains for their ability to nodule and fix $\mathrm{N}_{2}$ under saline conditions (Subba Rao et al, 1990).

\section{Tield response to inoculation}

The field performance of inoculation is variable. Not many on-farm data are available on the impact of inoculation on grain yields. In 12 trials with chickpea, inoculated plots gave on an average $116 \mathrm{~kg} \mathrm{ha}^{-1}$ more grain as compared to non-inoculated plots. In another set of field demonstrations, inoculation resulted in grain yield increase in the range of $112-227 \mathrm{~kg} \mathrm{ha}^{-1}$ (Chandra and Ali, 1986). The results of 1500 demonstrations on farmers' fields with pigeonpea conducted in Gulbarga district of Karnataka State in India showed $100 \%$ increase in yield $\left(1035\right.$ vs. $\left.516 \mathrm{~kg} \mathrm{ha}^{-1}\right)$ due to balanced use of DAP and Rhizobium inoculation (Chinmulgund and Hegde, 1987). On research stations in 16 trials inoculation of chickpea with Rhizobium increased grain yield by $342 \mathrm{~kg} \mathrm{ha}^{-1}$ (range $30-610$ ). Significant improvement in chickpea grain yield was reported from 7 out of 16 locations (Subba Rao, 1976) and 6 out of 12 locations (Subba Rao and Tilak, 1977), predominantly in central and northern India with yields varying from -14 to $30 \%$ compared to the control plots yield. Increase in grain yield of the pigeonpea inoculated with effective Rhizobium ranged from 19 to $68 \%$ over non-inoculated controls (Nambiar et al., 1988). In groundnut, inoculation responses varied from 
Table 12. Effect of fungicide and method of inoculation on nodulation by strain $\mathrm{NC9}^{\circ}$ on groundnut

\begin{tabular}{lccc}
\hline \multirow{2}{*}{ Treatment } & \multicolumn{3}{c}{ Method of inoculation and } \\
\cline { 2 - 4 } & Liquid & Seed & Uninoculated formed by strain NC $92^{a}$ \\
\hline Untreated & $30(27)$ & $22(20)$ & $4(2)$ \\
Captan & $28(23)$ & $7(4)$ & $3(1)$ \\
Thiram & $25(18)$ & $6(4)$ & $7(2)$ \\
Dithane & $19(10)$ & $14(9)$ & $7(3)$ \\
Bavistin & $24(16)$ & $1498)$ & $10(3)$ \\
Mean & $25(19)$ & $1399)$ & $6(2)$
\end{tabular}

SE mean for comparing inoculation means within a fungicide treatment is \pm 5.5 .

a Nodules typed by ELISA 60 days after sowing Data analysed after arcsine transformation: original means in parenthesis.

Source: Nambiar (1985).

decreased yields to significantly increased yields over non-inoculated controls (Kulkami and Joshi, 1988; Nambiar et al., 1988; Subba Rao, 1976). Over 228 inoculation trials were conducted under the International Network of Legumes Inoculation Trials (INLIT) by cooperating scientists in 28 countries over the years. In approximately $52 \%$ of the cases, inoculation resulted in significant yield increases (Davis et al., 1985). In summary, yield responses to inoculation were site specific, depending on location, species, fertility, and other factors.

Sometimes, legumes yields are not increased by inoculation but $\mathrm{N}$ concentration in grains or plant parts is increased over $\mathrm{N}$ concentration in non-inoculated control plants. In cases where both types of responses are not observed, it might simply result in a saving of soil $\mathrm{N}$ which might be useful for the succeeding crop.

\section{Conclusion and future areas of research}

Biological nitrogen fixation plays an important role in sustaining productivity of the soils in the SAT. Legumes fix substantial amounts of nitrogen (Table 1) through the BNF process and play an important role in the $\mathrm{N}$ cycle. However, mere inclusion of legumes in the cropping systems in the SAT will not ensure $\mathrm{N}$ contributions to the system through BNF. The important issue is how best we can exploit BNF technology for developing sustainable cropping systems in the SAT?

Until now considerable effort in BNF research has gone in the area of selection of efficient bacterial strains for using as inoculants. For realizing the maximum benefits from BNF we must take a holistic approad (Bantilan et al., 1994; Wani et al., 1994a). There is need to understand the BNF system which includes host, bacterium and environment and ensure that all the partners involved work in harmony to deliver maximum benefit. There is a need to accurately quantify $\mathrm{N}_{2}$ fixation by legumes in a system after taking into account the $\mathrm{N}_{2}$ fixed in the roots and fallen plant parts. Such information will help us to identify the systems which really maintain or improve the soil $\mathrm{N}$ status. Host controlled factors play an important role in regulating $B N F$ but have not received its due share by researchers. We need to identify type of legume and also genotype of a given legume which yields more and also derive larger part of its $N$ requirement from fixa. tion in a particular cropping system. For example, we need to identify crops and genotypes of legumes which can fix more $\mathrm{N}_{2}$ under sole cropping and intercropping situations without being affected by high mineral $N$ contents in soil. There is a need to identify host gene types which can fix well under adverse soil conditions like soil acidity, Al and $\mathrm{Mn}$ toxicity, alkalinity, water logging, etc.

At ICRISAT nonnodulating lines of chickpea, pigeonpea and groundnut have been developed from the existing cultivars andor segregating populations. Natural occurrence of nonnodulating plants ranged from 120 to 490 per million plants and efforts are required to see that occurrence of such plants do not increase. Most of the breeding and testing work is done at the research stations where mineral $\mathrm{N}$ contents are far higher than observed on the farmers fields. There is every likelyhood that low-or nonnodulating plants 
may not be identified as they will grow normally using soil N. To avoid this, appropriate checks during breeding and testing for discarding low-nodulating plants must be buill in the breeding programs.

Along with the selection of appropriate host plant and genotypes there is need to provide optimum management practices to ensure maximum contribution from the BNF. Through appropriate management practices soil $\mathrm{N}$ should be manipulated in intercropped situations for example appropriate form of fertilizer like slow releasing formulations, organic $\mathrm{N}$ and suitable method of application for example placement between cereal rows rather than broadcasting and mixing in the soil must be worked out. Appropriate amendments with nutrients other than $\mathrm{N}$ which might limit the plant growth and BNF should be done.

Suitable land management practices which can improve water storage capacity of soils or which can Jrain excess water away from the plant depending on the situation need to be used to harness maximum benefits from BNF. Efforts for selection of efficient strains of bacteria to use as inoculants and identification of specific host-bacteria combinations must go on. Situations which need inoculation should be identified and efforts for success to inoculation in such areas must be eoncentrated.

For increasing crop yields through biofertilizers, the following strategy is suggested. Most important constraints to effective exploitation of BNF technology in the SAT are:

- the quality of the inoculants

- lack of knowledge about inoculation technology

for the extension personnel and the farmers.

- effective inoculant delivery system

- formulation of the policy to exploit BNF successfully.

The history of inoculant manufacture and of many train collections is full of examples of organisms which look like rhizobia but are not! Contaminated cultures contribute to the problems which placed the inoculant industry of Australia in peril in the early 1950s. Many inocula of poor quality were sold and the losses at sowings of new legumes into poor soils were enormous (Thompson, 1982). This was repeated in India during the late 1970 and early 1980 s. Several thizobial inocula from the Indian manufacturers were examined at ICRISAT (Thompson, 1982) for their infectivity tests. Irrespective of private or public institution origin, the majority failed to pass the published standards (ISI, 1977). There must be strict quality control mandatory on all biofertilizer producers irrespective of their status as private/public or government organization.

For success of biofertilizers in the SAT concerted efforts right from production, demonstration to distribution will be required. The next step is convincing and educating the farmers regarding the benefits of these inoculants. The pricing of the biofertilizers must be controlled if private agencies are involved, otherwise if farmers don't see the significant effects in term of economic yields, they may not be interested in using the biofertilizers. There is a need to demonstrate the benefits from BNF technology in terms of maintenance or improvement of soil fertility through longterm experiments. At this stage the policy issue arises that biofertilizers should be used or considered as an insurance for harnessing BNF to its maximum potential taking systems approach. As discussed earlier the nonnodulating or LN plants look similar in appearance to well nodulated plants in chickpea but this is at the eost of soil or fertilizer $\mathrm{N}$. We must take the view that in the end we may derive benefit in terms of maintaining or improving the productivity of our soils, We should not be disappointed by not seeing the direct benefits in terms of increased legume yields in some cases. A holistic approach to improve production of legumes is needed and we must ensure that all the constraints for good plant growth other than $\mathrm{N}$ nutrition are alleviated and suitable management practices are provided for better performance of BNF technology.

\section{Acknowledgements}

We thank Mr P N Murthy for wordprocessing this document, Mrs $S$ Rajeswari for freelance graphics and two anonymous reviewers for their critical comments on the manuscript.

\section{References}

AICORPO 1983 All India Coordinated Research Project on Oilseeds.Annual Progress Report, Kharif 1982, 2, 24l-248, Rajenderanozar, Hyderabad, India,

Ahlawat I S S, Singh A and SarafC S 198 I Effects of winter legumes on the nitrogen economy and productivity of succeedirig cereals. Exp. Agric. 17,57\%2.

Alexander M 1982 Research to enhance nitrogen fixation misplaced emphasis? In Priorities in Biotechnology Research for International Development pp 209-229. National Academy Press, Washington $D C$.

Arunachalam $V$, Pungle $G \mathrm{D}$, Dutta $\mathrm{M}$, Nambiar $\mathrm{P} \mathrm{T} \mathrm{C}$ and Dart P. I 1984 Efficiency of nitrogenase activity and nodule mass in 
predicting the relative performance of genotypes assessed by a number of characters in groundnut (Arachis hypogaea). Exp. Agric. 20, 303-309.

Bandyopadhyay S K and De R 1986 Nitrogen relationships and residual effects of intercropping sorghum with legunes. I. Agric. Sci. (Camb) 107, 629-632.

Bantilan M C S, Johnsen C and McDonald D 1994 Expectations fromBNF research - Research administrators" point of view, In Linking Biological Nitrogen Fixation Research in Asia: Report of a Meeting of the Asia Working Group on Biological Nitrogen Fixation in Legumes. Eds. O P Rupela, I $\vee$ D K Kumar Rao, C Johansen and S P Wani. pp 61-90. Intsmational Crops Research Institute for the Semi-Arid Tropics, Patancheru, Andhra Pradesh, India.

Betts I H and Herridge D F 1987 Isolation of soybean lines capable of nodulation and nitrogen fixation under high levels of nitrate supply. Crop Sci. 27, 1156-1161.

Blevins R L, Herbek J H and Fyre W W 1990 Legume cover crops as a nitrogen source for nowtill corn and grain sorghum. Agron $)$. 82,769 .

Bonnier C 1960 Symtiose Rhizobium-leguminouses: Aspects particuliers aux regions tropicales. Ann. Inst. Pasteur, Paris 98, 537 556.

Brockewell J, Gault R R, Chase D L, Hely F W, Zorin M and Corbin E J 1980 An appraisal of practical alternatives to legumes seed inoculation: Field experiments on seed bed inoctiationwith solid and liquitd inoculants. Aust. J. Agric. Res. $31,47-60$.

Buresh R I and De Datta S K 1991 Nitrogen dynaraics and management in rice-legume cropping systerns, Adv. Agron, 45, 1-59.

Zburns R C and Hardy R W F 1975 Nitrogen fixation in bacteria and higher plants. Springer-Verlag, Berlin. 189p.

Burton J C 1982 Modem concepts in legume inoculation In Biological Nitrogen Fixation Technology for Tropical Agriculture. Eds. P H Grahm and S C Harris. pp 105-114. CIAT, Cali Colombin.

Buttery B R and Dirks $\vee$ A 1987 The effects of soybean cultivar, Rhizobium strain and nitrate on plant growth, nodule mass, and acetylene reduction rate. Plent and Soil 98, 285-293.

Buttery B R and Gibson A H 1990 The effect of nitrate on the time course of nitrogen fixation and growth in Pisum satwum and Vicia faba. Plant and Soil 127,143-146.

Butrery B R, Park S J, Finday W I and Dhanvantari B N 1988 Effects of fumigation and fertilizer on growth, yield, chemical composition and mycornhizae in white bean and soybean. Can. J. Plant Sci. 68, 677-686.

Buttery B R, Park S I and Dhanyantari B N 1990 Effect of combined nitrogen, Rhizobim strain and substrate on a supemodulating mutant of Phaseolus valgarig L, Can.J. Plant Sci. 70, 955-963.

Carroll B J, McNeil D L and Gresshoff P M 1985 A supernodulation and nitrate-tolerant symbiotic (nts) soybean mutant. Plant Physiol. 78, $34-40$.

Cassman $\mathrm{K} \mathrm{G}$, Whitney A S and Fox R L 1981 Phosphorus requirem ments of soybean and cowpea as affected by mode of $N$ nutrition. Agron. J. 73, 17-22.

Chalk P M 1991 The contribution of associative and symbiotic nitrogen fixation to the nitrogen nutrition of non-legumes. Plant and Soll $132,29-39$.

Chandra $\$$ and Ali M 1986 Recent achievements in pulses production. Tech. Bull. No. 1, Directorate of Pulse Research, ICAR, Kanpur. 44 p.

Chinmulgund $\mathrm{V} \mathbf{K}$ and Hegde $\mathrm{S} V 1987$ Increasing redgram yields through diammonium phosphate (apphication) and Rhizobium (inoculation) treatment. Fert. Mkt. News, 18, 9-13.

Cho M-J and Haper J E 1991 Effect of localized nitrate application on isoflavonoid concentration and nodulation in split-root sys- tems of wild-type and nodulation-mutant soybean plants. Plant Physiol. 95, 1106-1112.

Cook R J 1988 Biological control and holistic plant-health care in agriculture. Am. J. Alten. Agric. 3, $51-62$

Dakora FD, Aboyinga F A, Mahama $Y$ and Apaseku J 1987 Assessment of $\mathrm{N}_{2}$ fxation in groundnut (Arachis hypogaed L.) and cowpea (Vigna unguicalata L. Walp) and their relative $\mathrm{N}$ contribution to a succeeding maize crop in northem Ghana. MIRCEN J. 4, 389-399.

Danso S K A and Papastylinou I 1992 Evaluation of the titrogen contribution of legumes to subsequent cereals. J. Agric. Sel. 119. $13+18$.

Davis R J, Cady F B, Wood C L and Chan C P Y 1985 Design and analysis of an Intemational Experimental Network: Legume inoculation trials in the NirTAL project. INLIT experiences. Research Series 042, College of Tropical Agricalture and Human Resources, University of Hawail, Honolulu.

De $\mathrm{R}$ and Gautam R C 1987 Mantagement practices to increase and stabilize pearl miliet production in India. In Proceedings of the Intemational Pearl Millet Workshop. Ed. I R Witcombe, pp 247 253. ICRISAT, Putaneheru, India.

De R, Yogeswara $Y$ and Ali $W 1983$ Grain and fodder legumes as preceding crops affecting the yield and $\mathrm{N}$ economy of rice. Agric. Sei. Carnb. 101, 463-466.

Doughton I A and Mackenzie I 1984 Comparative effects of black and green gram (mung beans) and grain sorghum on soil mineral nitrogen and subsequent grain sorghum yields on the eastern Darling Downs. Aust. J. Exp. Agric. Arim. Husb. 24, 244-249.

Doughton $J A$, Valis $I$ and Saffina $P G 1993$ Nitrogen fixation in chickpea. I. Infuence of prior cropping or fallow nitrogenfertilizer and tillage. Aust. J. Agric. Res, 44,1403-1413.

Francis C. A 1986 In Multiple Cropping Systems. Macmillan, New York. $383 \mathrm{p}$

Funcis C A and Clegg M D 1990 Crop rotations in sustainable production systems. In Sustainabie Agricultumal Systems. Ed. C A Edwards. p 107. Soil and Water Conservation Society, Ankeny, 10.

Francis C A, Harwood R R and Parr J F 1986 The potential for regenerative agriculture in the developing wotld. Am. J.Altern. Agric. 1, 65 .

France C A 1977 Contribution of the legume-rhizobium symbiosis to the ecosystem and food production. $I n$ Exploiting the LegumeRhizobium Sympositum in Tropical Agriculture. Eds. J M Vincent et al. pp 237-252. University of Hawai, USA.

Fujita K, Ofosu.Budu K G and Ogata S 1992 Blological nitrogen fixation in mixed legume-cereal cropping systems. Plant and Soil, 141. $155-175$.

Fyson A and Oaks A 1990 Growth promiton of nnize by legume solls. Plant and Soil 122, 259-266.

George $T$, Ladha I K, Buresh R J and Garrily D P 1992 Managing native and legume-fixed nitrogen in lowland rice-based cropping systems. In Biological Nitrogen Fixation for Sustainable Agricolture. Eds. I K Ladha, T George and B B Bohlool. pp $69-92$. Kluwer Academic Publishers, Dordrecht.

Gibson A H and Harper I E 1985 Nitrate effect on nodulation of soybean by Aradymizobium japonicum. Crop Sci. 25,497-501.

Giller K E, Nambiar P T C, Srinivasa Rao B, Dart P J and Day J M 1987 A comparison of nitrogen fxation in genolypes of groundnut (Arachis hypogaea L) using ${ }^{15} \mathrm{~N}$-isotope dilution. Biol. Fertil. Solls $5,23-25$.

Graham P H and Rosas J C 1977 Growth and developnent of intermediate bush and climbing cultivars of Phaseolys vulgaris $\mathrm{L}$. inoculated with Rhizobiun J. Agric. Sci, Camb. 88, 503-508. 
Graham P H and Rosas 1 C 1978 Plant and nodule development and nitrogen foxation in climbing cultivars of Phaseolus utgaris $\mathbf{L}$. grown in monoculture or associated with $Z_{e a}$ mays $L$. J. Agric. Sci., Camb. $90,311-317$.

Hansen A P Peoples M B, Gresshoff $P$ M, Alkins C A, Pate I S and Carroll B $\mathrm{J} 1989$ Symbiotic performance of super-nodulating soybean (Gycine max (L.) Merrill) mutants during development on different nitrogen regimes. J. Exp. Bot. 40,715-724.

Hardarson G, Zapata F and Danso S K A 1984 Effect of plant genotype and nitrogen fertilizer on symbtotic fixation by soybean cultivars. Plant and Soll 2, 397-405.

Hardarson G, Golbs $M$ and Danso S K A 1989 Nitrogen fixation in soybean (Glycine max L. Merrill) as affected by nodulation patterns. Soil Biol. Biochern. 21, 783-787.

Herridge D F, Bergersen $\mathrm{F} I$ and Peoples M B 1990 Measurement

of nitrogen fixation by soybean in the field using the ureide and natural abundance methods. Plant Physiol, 93, 708-716.

Herridge D.F. Marcellos H, Helton W L. Tumer G L and Peoples M. B 1994 Chickpea increases soli-N fertility in cereal systems through nitrate sparing and $\mathrm{N}_{2}$ fixation. Soil Biol. Biochem. (In press).

Hesterman $O B$, Russelle $M P$, Sheafter $C, C$ and Heichel $G H$ 1987 Nitrogen utilization from fertilizer and legume residus in legume-corn rotations. Agron. J. 79, 726-731.

IARI 1980 The energy problems of agriculture and development of renewable resources. In Scientific Baxis of Indian Agriculture: Seventyfive Years of Service. pp 189-209. Indian Agricultural Research, New Delhi, India.

ICRISAT 1981 ICRISAT Annual Report for 1979-80. pp 91-94. International Crops Research Institute for the Semi-Arid Tropics, Patancheru, AP. India.

ISI 1977 Specifications for Rhizobium Inoculants. Indian Standards. $8268 \mathrm{p}$.

Jefing X, Herridge D F, Peoples M B, and Rerkasem B 1992 Effects of $\mathrm{N}$ fertilization on $\mathrm{N}_{2}$ fxation and $\mathrm{N}$ balances of soybean grown after low land rice. Plant and Soil 147,235-242.

Johanson T B, Turpin F T, Schniber M M and Griffith D R 1984 Effeets of crop rotation, tillage, and weed managementsystems on black cutworm (Lepidoptera: Noctuidae) infestations in com. I. Econ. Entomol. 77,919.

Joshi P K, Bhat D M and Kulkarn I H 1987 Groundnut root nodulation as affected by micronutriens application and Rhizobium inoculation. Int. J. Trop. Agric. 5,199-202.

Kabi M C and Poi S C 1988 Improvement of pulse cultivation in West Bengal through effective use of Rhitobim. In Biofertilizers Potentialities and Problems, Eds. S P Sen and P Palit. pp 35-44. Naya Prakash, Calcutta.

Kapusta $G$ and Rouwenhorst D L 1973 Influence of inoculum size on Rhizobitan faponhan serogroup distribution frequency in soybean model. Agron. J. 65, 916-919.

Keyser H $H$ and Li F 1992 Potenial for increasing biclogical nitrogen fixation in soybean. Plant and Soil 141,119-135.

Khurana A L and Dudeja S S 1981 Field populations of rhizobia and response to inoculation, molybdenum and nitrogen fertilizer in pigeonpea. In Proceedings of the Intemational Workshop on Pigeonpea. Vol. 2, pp 381-386. 15-19 December 1980, ICRISAT Center, India. Patancheru, AP, ICRISAT, India.

Kucey R M N, Chaitanakupt $P$, Arayangkool T, Snitwongse $P$, Siripaibool C. Wadistrisuk. Pand Boonkerd N 1988 Nitrogenfixation ( ${ }^{15} \mathrm{~N}$ diludon) with soybeans under Thai field conditions. II. Effect of herbicides and water application schedule. Plant and Soil 108, 87-92.

Kulkarni J H., and Joshi P K 1988 Rhizobum incculation studies in groundnut: Problems and prospects. in Biofertilizers Potential- ities and Problems. Eds. S P Sen and P Palit. pp 51-56. Naya Prakash, Calcutta.

Kumar Rao J V D K and Dart PJ 1981 Effect of different plant growth media on nodulation growth and nutrient uptake of pigeonpea. In Proceedings of the International Workshop on Pigeonpeas. Vol 2. pp 403-408. 15-19 December 1980, ICRISAT Center, India. Patancheru, AP, ICRISAT, India.

Kumar Rao J V D K and Dart P J 1987 Nodulation, nítrogen fixation and nitrogen uptake in pigeonpea (Cajanks cajzh (L.) Millsp.) of different maturity groups. Plant and Soll 99,255 266.

Kumar Rao J V D K and Sithanantham S 1989 Impact of nodule damage by Rivellia angulata on $\mathrm{N}_{2} \times$ fixation, growth and yield of pigeonpea (Cajarus cajan (L) Millsp.) grown in a Vertisol. Biol. Fertil. Soils 7, 95-100.

Kumar Rao JV D K, Dart PJ and Sastry P V S S 1983 Residual effect of pigeonpea (Cajanus cajan) on yield and nitrogen response of maizz. Exp. Agric. 19, 131-141.

Ladd J N, Oades J M and Amato M 1981 Distribution and recovery of nitrogen from legume residues decomposing in soils sown to wheat in the feid. Soll Biol. Biochem. 13, 251-256.

Ladd IN, Amato M, Jackson R B and Butler J H A 1983 Utilization by wheat crops of nitrogen from legume residues decomposing in soils in the field. Soil Biol. Biochem. 15(3), 231 ..238.

Ladha J K, Tirol-Padre A. Punzalan C C, Garcia $M$ and Watanabe I 1989 Effect of inorganic $\mathrm{N}$ and organic fertilizers on niltrogenfixing (acetylene-reducing) activity associated with wetland riceplants. In Nitrogen Fixation with Non-Legumes. Eds. F A Skinner, R M Boddey and I Fendrik op 263-272. Kinwer Academic Pubitishers, Dordrectit.

Latif M A, Mehuys G R, Mackenzie A F, All I and Faris M A 1992 Effects of legumes on soll physical quality in a maize crop. Plant and Soll 140, 15-23.

Lee K K, Wanf, SP, and Anders M M 1993 Nutrient and waretboiance study on an Alfisol. In Resource Management Program Quarterly Report, July-September, 1993: pp 41-42. Intemational Crops Research Institute for the Semi-Arid Tropics, Pataniheru, Andhra Pradesh, India.

Maccol D 1989 Studies on maize (Zea mays) at Bunda, Malawi. II. Yield in short rotations with legumes. Exp. Agric. $25,367-374$.

Nambiar P T C 1985 Responses of groundnut (Arachis hypogatea L.) to Rhizobium inoculation in the field: problems and prospects. MIRCEN I. 1, 293-309.

Nambiar P T C 1990 Nitrogen nutrition of groundnut in Altisols.Information Bulletin No. 30. pp 1-30. Intemational Crops Reseatch Institute for the Semi-Arid Tropics, Patancheri; AP, India.

NambiarPTC, Dart P J Srini asa Rao B and Ravishankar HN 1982 Response of groundnut (Amchis hypogatea) toinoculation. $\mathrm{I}$ Biological Nitrogen Fixation Technology for Tropical Agriculture. Presented at a Workshop, 9-13 March 1981, Cali, Columbia. Eds. P H Graham and S C Harris pp 241-248. Centro Intemacional de Agricultura Tropical, Cali, Colombia.

Nambiar P T C, Rao M R, Reddy M S Floyd C, Dart P J and Willey $\mathrm{R}$ W 1983 Effect of intercropping on nodulation and $\mathrm{N}_{2}$ fixation by groundnut. Exp. Agric. 19, 79-86.

Nambiar P T C, Stinivasa Rao B, and Anjaiah V 1984 Studies on competition, persistence and methods of application of a grouninut Rhizobium strain NC92. Peanur Sci. 11,83-87.

Nambiar P T C and Anjaiah V 1989a Effect of manganese toxicity on growth and $\mathrm{N}_{2}$ fxation in groundnut, Arachis hypogaea. Ann. Appl. Biol. $115,361-366$.

Nambiat P T C and Anjaiah V 1989 b Competition among strains of Bradyhtizobian and vesicular-arbuscular mycorthizae for 
groundnut (Arachis hypogaea L) root infection and their effect on plant growth yleld. Biol. Fertil. Soils $8,311-318$.

Nambiar P T C, Rego T I and Srinivasa Rao B 1986 Comparison of the requirements and utilization of nitrogen by genotypes of sorghum (Sorghum bicolor) and nodulating and non-nodulating groundiut (Arachis hypogata L.). Field Crops Res. 15, $165-179$.

Nambiar P T C. Rupela OP and Kumar Rao J V DK 1988 Nodulation and nitrogen fxation in groundnut (A rachis hypogata L.), chickpea (Clcar arietinum), and pigeonpea (Cajants cajan L Milsp). In Biological Nitrogen Fixation: Recent Developments. Ed. N S Subba Rao. pp 53-70. Oxford and IBH Publishers, New Delhi.

Nambiar P T C, Ma S W and Aiyer V N 1990 Limiting an insect infestation of nitrogen-fixing root nodules of the pigeonpea (Cajauts cajan by engineering the expression of an entomocidal gene in its root nodules. Appl. Environ. Microbiol. 56, 2866-2869,

Namdeo S L and Gupta S C 1992 Response of puises to microbial inoculants - A review of the work done at Sehore (MP). In National Seminar on Organic Farming. Eds, M M Rai and L N Verma. pp 150-161. Jawaharlal Nehn Krishi Vishwa Vidyalaya, Jabalpur, MP, India.

Nigam S N, Dwivedi S L, Nambiar P T C, Gibbons R W, and Dart P / 1985 Combining ability analysis of $\mathrm{N}_{2}$-fixation and related traits in pearut. Peanut Sci. 12,55-57.

Norhayati $M$, Mohd Noor $S$, Chong $K$. Faizah A W, Herridge D F, Peoples M B and Bergersen F J 1988 Adaptation of methods for evaluating $\mathrm{N}$, fixation in food legumes and legume cover crops. Plant and Soll 108, 143-150.

O'Hara G W, Dilworth M J, Boonkerd N and Parkpian P 1988 Iron-deficiency specifically hmits nodule development in peanut inoculated with Bradyrhizobium sp. New Phytol.108, 51-57.

Ofor $F$ and Sten W R 1987 Cereal-legume intercropping systems. Adv. Agron. 41, 41-90.

Ofori F, Pate $\mathrm{J} S$ and Stern W R 1987 Evaluation of $\mathrm{N}_{2}$ fixation and nitrogen economy of a maize/cowpea intercrop system using ${ }^{15} \mathrm{~N}$ dilution methods. Plant and Soil 102, 149-160.

Ogata S, Fujitn K, Matsumoto K and Saneoka H 1986 Studies on mixed croping of grasses and legumes. 1. Dry matter production and behavior of fixed $\mathrm{N}$ in the system of mixed cropping sorghum, soybean and siratro. J. Jpn. Grausl. Sci. 32, 36-43 tin Japanese wifh English summary).

Olmstad L B 1947 The effect of longtime cropping systems and tillage practices upon soil aggregution at Hays, Kansas. Soil \$ci. Soc. Am. Froc, 11, 89.

Prasad R, Sharma S N, Singh S and Prasad M 1990 Nitrogen man* agement. In Soil Fertility and Fertilizer Use, Vol. IV Nutrient Management and Supply System for Sustaining Agriculture in 1990s. Eds. Virendra Kumar, G C Shrotriya and S Y Kaore. pp 41-51. PR Department, Marketing Division, IFTCO, New Delhi.

Peoples M B and Heridge D F 1990 Nitrogen fixation by legumes in tropical and sub-tropical agriculture. Adv. Agron, 44, 155-223.

Peoples M and Crasswell E T 1992 Biological nitrogen fixation: Investments, expectations and actual contributions to agricuiture. Plant and Soil 141, 13-39.

Peoples M B, Sudin M N and Herridge D F 1987 Translocation of nitrogenous compounds in symbiotic and nimate-fed amide exporting legumes. J. Exp. Bor. 38, 567-579.

Power J F 1990 Legumes and crop rotations. In Sustainable Agriculture in Temperate Zones. Eds. C A Francis, C B Flora and L D King. p 178. Wiley, New York.

Raj A S 1987 Cobalt nutrition of pigeonpesa and peanut in relation to growth and yteld. J. Flant Nutr. 10,2137-2145.

Rao C C S and Singh KD 1991 Effect of residual greengram(Vigna radiata $\mathrm{L}$. Wilczek) after maize-wheat sequence on soil available nitrogen, phosphorus and potassium. Legume Res. 14,125-130.
Rawsthorne S, Hadley P, Summerfield R I and Roberts E H 1985 Effect of supplemental nitrate and thermal regime on the nitrogen nutrition of chickpea (Cicer ariefinum L.) II. Symbiotic development and nitrogen assimilation. Plant and Soil 83, 279-283.

Rego $\mathrm{T} \mathrm{J}$ and Burford J R 1992 Sustaining crop productivity on rainfed Vertisols through grain legumes. Agron. Abstr. Annual Meetings, American Society of Agronomy, Crop Science Society of America, Soil Science Society of Ametica, Clay Minerals Society, Minnenpolis, Minnesota, USA. Nov 1-6. 1992. 289p.

Rennie R J, Dubetz S, Bole J B and Muendel H H 1982 Dinitrogen fixation measured by ${ }^{15} \mathrm{~N}$ isotope dilution in two Canadian soybean cultivats. Agron. J, 74, 725-730.

Rennie R J and Kemp G A $1982 \mathrm{~N}_{2}$-fixation in field beans quantifed by ${ }^{13} \mathrm{~N}$ isotope dilution. II. Effect of cultivars and beans. Agron. J. $75,645-649$.

Ries S K, Sweeley V W C C and Leavit R R 1977 Tricontanol: A new naturally occurring plant growth regulator. Science 195,1339. 1341.

Roy Sharma R P and Singh Ambika 1969 Residual effect of lerumes in winter legume-maize rotation. Indian I. Agric. Sci. 39, 530539.

Rupela O P 1992 Natural occurrence and sallent characters of nonnodulating chickpea plants. Crop \$ci, 32, 349-352.

Rupela O P 1994 Sereening for intracultivaral variability for nodula tion of chickpea and pigeonpea. $I n$ Linking Biological Nitrogen Fixation Research in Asia; Report of a meeting of the Asia Working Group on Biological Nitrogen Fixation in Legumes. Eds. $O$ P Rupela, J V D K Kumar Rao, S P Wani and C Johansen. pp 75- B3. International Crops Research Institute for the Semi-Arid Tropics, Patancheru, Andhra Fradesh, India.

Rupela O P and Joharsen C 1995 Identifieaton of nonnodulating, and low and high nodulating plants in pigeonpea. Soil Biol. Biochem. (Special Volume) (In press).

Rupela O P and Saxena M C 1987 Nodulatiou and nitrogen fixation in chickpea. In The Chickpea. Eds, M C Saxena and K B Singh. pp 191-206. CAB International, Walingford, Oxfordshire, UK.

Rupela O P, Sudarshana M R and Thompson I A 1985 Sowing depth can determine nodulation pattem in chickpea. In Nitrogen Fixation Research Progress. Eds. H J Evans, P J Bottomiey and W E Newton. P320. Martinus Nijhoff Publishers, Dordrecht.

Rupela O P, Toomsan B, Mitual S, Dart P J and Thompson J A 1987 Chickpea Rhizobium poptlations: Survey of infuence of season, \$oil depth and cropping pattern. Soil Biol. Biochem. 19, 247-252.

Russelle M P, Hesterman O B, Sheaffer C C and Heichel G H 1987 Estimating nitrogen and rotation effects in legume-comrotations. In The Role of Legumes in Conservation Tillage Systems. Ed. T F Power p 41 . Soil Conservation Society, Washington, DC.

Sawhey $Y$, Amarjit Sheoran IS and Singh R 1989 Effect of shor term nitrate application on nodule metabolism in chickpea $C$ icer arietinum L. Indian J. Exp. Biol, 27, 220-223.

Senaratne $R$ and Hardarson $G 1988$ Estimation of residual $N$ effect of faisabean and pea on wo succeeding tereals using ${ }^{15} \mathrm{~N}$ methodology. Plant and \$oil 110.81-91.

Sithanantham S, Kumar Rao I V D K, Reed W and Dart P J 1981 Studies on nodule damage in pigeonpea. $/ n$ Proceedingsof the International Workshop on Pigeonpeas. Vol. $2, p p$ 409-415. ICRISAT Center, India. ICRISAT, Patancheru, AP, India.

Somaseguran P and Bohlool B B 1990 Single-stmin versus multi strin inoculation. Effect of soil mineral $\mathrm{N}$ gvailability on rhizobial strain effectiveness and competition for nodulation of chickpea, soybean and dry bean. Appl, Environ. Microbiol. 56. 3298 3303. 
Ssali $\mathrm{H}$ and Keya $\$$ O 1984 Nitrogen level and cultivar effects on nofulation, dinitrogen fixation and yield of grain legumes. I. Cowpen cultivars. East. Afr. Agric. J. 45,247-254.

Ssali $H$ and Keya $\mathrm{SO} 1986$ The effects of phosphorus and nitrogen fertilizer level on nodulation, growth and dinitrogen fxation of three bean cultivars. Trop. Agric. (Trüidad) 63, $105-109$.

Strickling E 1950 The effect of soybeans on volume weight, and water stability of aggrigates, soil organic matter content and crop yield. Soil Sci. Soc. Am Proc. 15, 30.

Subba Rao N S 1976 Field response of legumes in India to inoculation and fertilizer appliations. In Symbiotic Nitrogen Fixation in Flants. Ed. P S Nutman. pp 265-288. Cambridge University Press, London.

Subba Rao N S and Tilak K V B R 1977 Rhizobial cultures - their role in pulse production. In Souvenier Bullecin, Directorate of Pulse Development. Ed. N S Subba Rao. pp 1-19. Oxford and IBH, New Delhi.

Subba Rao G V, Johansen $C$, Kumar Rao I V D K and Iana $M$ 1990 Responss of the pigeonpez-Rhizobium symbiosis to salinity stress: Variation among Rhizobium strains in symbiotic activity. Biol. Fertil, Soils 9.49-53.

TAC CGIAR 1988 Sustainable agricultural production: Implícations

for international agricultural research. CGIAR (ConsultativeGroup on International Agricultural Research) meeting, Berlin.

Tandon H L S 1992 Fertilisers and their integration with organic and biofertilisers. In Fertilisers, Organic Manures, Recyclable Wastes and-Biofertilisers. Ed. H L S Tandon. pp 12-36. Fertiliser Development and Consultationorganisation, 204-204A Bhanot Comer New Delhi.

Tauro $P$ and Khurana A L 1986 Problems and prospects of growth, extension and promotion of biofertilisers. $/ \mathrm{h}$ Proceedings of the FAI Seminar. PP $1-4$, Growth and Modernisation of Fertiliser Industry, PS 111, Fertiliser Association of India, India.

Thies JE, Singleton P W and Bohlool B B 1991 Modeling symbiotic perfomance of introduced rhizobia in the feld by use of indices of indigenous population size and nitrogen status of the soil. Appl. Environ. Mierobiol. 57, 29. 37.

Thomas G W, Blevins R L, Philips R E and McMahon M A 1973 Effect of a killed sod muleh on nitrate movement and corn yield. Agron. J. 65, 736-739.

Thompson J A 1982 Inocularis and ecology of Rhizobium. In Biological Nitrogeu Fixation. pp 49-64. Bhabha Atomic Research Center, Trombay, Bombay.

Troll C. 1965 Seasonal climates of the earth. In World Maps of Climatology. Eds. E Rodenwalt and H Jaskatz. p 28. Springer Verlag, Berlin.

Wallis 1983 Uptake by grass and transfer of soil of nitrogen from

I.5 $\mathrm{N}$-labelled legurne materials applied to a Rhodes grass pasture. Aust. J. Agric. Res. 34, 367-376.

Venkateswaru B and Kalyal J C 1994 improvement of nitrogenfixatiou in groundnut by host-piant selection. In Linking Biological Nitrogen Fixation Research in Asia: Report of a meeting of the Asia Workitg Group on Biological Nitrogen Fixation in Legumes. Eds. O P Rupela, J V D K Kumar Rao, S P Wani and C Johanson, 6-8 December 1993. International Crops Research Institute for the Semi-Arid Tropics, Patanchert, Andhra Pradesh, India.

Wacek T J and Brill W J 1976 Simple, rapid assay for screening nitrogen-fixing ability in soybean. Crop Sci, 16, 519-523,

Wahua T A T and Miller D A 1978 Effects of shading on the $\mathrm{N}_{2}$ fixation, yleld and plant composition of field-grown soybeans. Agron. J. 70, 387-392,

Wani S P and Lee K K 1992 Role of biofertilisers in upland crop production. In Fertitisers Organic Manures Recycle Wastes and Biofertilisers. Ed. H L S Tandon. pp 91-112. Fertiliser Development and Consulation Organization, 204-204A, Bhanot Coner, New Delhi.

Wani S P, McGill W B and Robertson I A 1991 a Soil N dynamics and $N$ yieid of barley grown on Breton loam using $N$ from biological ixation or fertilizer. Blol. Fertil. Soils $12,10 \mathrm{~m} 18$.

Wani S P. McGill W B and Tewari J P 1901 b Mycorhizal and com-

mon root infection, and nutrient accumulation in barley grown on Breton loam using $N$ from biological fixation or fertilizer. Bitol. Fertil. Soils 12, 46-54.

Wani S P, Rego T I and Kumar Rao J V D K 1994a Contribution of legumes in cropping systems: A long-term perspective. In Linking Biological Nitrogen Fixation Research in Asia: Report of a Meting of the Asia Working Group on Biological Nitrogen Fixation in Legurnes. Eds. O P Rupela, J V D K Kumar Rao, S $P$ Want and C Johanson. pp $84-90$ Intematonal Crops Research Institute for the Semi-Arid Tropics, Patancheru, Andhra Pradesh.

Wani S P, McGill W P, Haugen Kozyra K L and Juma N G $1994 \mathrm{~b}$ Increased proportion of active soll $N$ in Breton loan undercropping systems with forages and green manures. Can. J. Soil Sci.

Wani S P, McGill W B, Haugen-Kozyra K L, Robertsou I A and Thurston II $1994 \mathrm{c}$ Irnproved soil quality and barley yiejds with fabaleans, manure, forages and crop rotation on a grayluvisol. Can. J. Soil Sci. (In press).

Weaver R W and Frederick L R 1974 Effect of inoculum rate on competitive nodulation of Glycine max L. Merill. I Field studies. Agron. J. 66, 233-236.

Weil R R and Samamanake A 1991 Effects of winged bean on a following maize erop. Exp. Agric. 27, 329-338.

Westermann D T, Kleinkopf G E, Porter L K and Legett G E 1981 Nitrogen sources for bean seed production. Agron. J. 73,660-664.

Willey R W 1979 Intercropping-its importance and research needs: Part 2: Agronomy and research approaches. Field Crops Abstr. $32,73-85$.

Wu $S$ and Harper J E 1991 Dinitrogen fixation potential and yietd of hyper nodulating soybean mutants: A field evaluation. Crop Sci. $31,1233-1240$.

Yoneyama T, Nambiar P T C, Lee KK, Srivivasa Ra B and Williams I H 1990 Nitrogen accumulation in three legumes and two cereals with emphasis on estimation of $\mathrm{N}_{2}$ fixation in the legumes by the natural ${ }^{15} \mathrm{~N}$ abundance technique. Biol. Fertil. Soils $0,25-30$.

Zari KW, Milter ICIr, Weaver R W and Barnes L. W 1978 Intraspecific variability for nitrogen fixation in southem pea (Vigua unictilata). J. Am. Soc. Hortic. Sci. 103,806-808, 
s. 